OPEN ACCESS

Edited by:

Cristina Gambi,

Marche Polytechnic University, Italy

Reviewed by:

lan David Tuck,

Fisheries New Zealand, Ministry for Primary Industries, New Zealand

Lucia Bongiorni,

Institute of Marine Science, National

Research Council (CNR), Italy

*Correspondence:

Maria Montseny

montseny@icm.csic.es;

mariamontseny@gmail.com

Specialty section:

This article was submitted to Deep-Sea Environments and Ecology,

a section of the journal

Frontiers in Marine Science

Received: 25 October 2020

Accepted: 23 August 2021

Published: 13 September 2021

Citation:

Montseny $M$, Linares $C$,

Carreiro-Silva M, Henry L-A, Billett D,

Cordes EE, Smith CJ,

Papadopoulou N, Bilan M, Girard F, Burdett HL, Larsson A, Strömberg S, Viladrich N, Barry JP, Baena P,

Godinho A, Grinyó J, Santín A,

Morato T, Sweetman AK, Gili J-M and

Gori A (2021) Active Ecological

Restoration of Cold-Water Corals:

Techniques, Challenges, Costs

and Future Directions.

Front. Mar. Sci. 8:621151.

doi: 10.3389/fmars.2021.621151

\section{Active Ecological Restoration of Cold-Water Corals: Techniques, Challenges, Costs and Future Directions}

\author{
Maria Montseny ${ }^{1 *}$, Cristina Linares ${ }^{2}$, Marina Carreiro-Silva ${ }^{3}$, Lea-Anne Henry \\ David Billett ${ }^{5}$, Erik E. Cordes 6 , Christopher J. Smith ${ }^{7}$, Nadia Papadopoulou', \\ Meri Bilan ${ }^{3,8}$, Fanny Girard ${ }^{9}$, Heidi L. Burdett10, Ann Larsson ${ }^{11}$, Susanna Strömberg ${ }^{11}$, \\ Núria Viladrich ${ }^{2,12}$, James P. Barry ${ }^{13}$, Patricia Baena' ${ }^{1}$, Antonio Godinho ${ }^{3}$, Jordi Grinyó ${ }^{1,14}$, \\ Andreu Santín', Telmo Morato ${ }^{3}$, Andrew K. Sweetman', Josep-Maria Gili' and \\ Andrea Gori ${ }^{1,2,8}$ \\ ${ }^{1}$ Institute of Marine Sciences, Spanish National Research Council, Barcelona, Spain, ${ }^{2}$ Departament de Biologia Evolutiva, \\ Ecologia i Cienciès Ambientals, Institut de Recerca de la Biodiversitat, Universitat de Barcelona, Barcelona, Spain, \\ ${ }^{3}$ IMAR-Instituto do Mar, Instituto de Investigação em Ciências do Mar - OKEANOS da Universidade dos Açores, Horta, \\ Portugal, ${ }^{4}$ School of GeoSciences, University of Edinburgh, Edinburgh, United Kingdom, ${ }^{5}$ National Oceanography Centre, \\ Southampton, United Kingdom, ${ }^{6}$ Department of Biology, Temple University, Philadelphia, PA, United States, ${ }^{7}$ Hellenic \\ Centre for Marine Research, Crete, Greece, ${ }^{8}$ Dipartimento di Scienze e Tecnologie Biologiche e Ambientali, Università del \\ Salento, Lecce, Italy, ${ }^{9}$ Laboratoire Environnement Profond, Département Etude des Ecosystèmes Profonds, Institut Français \\ de Recherche pour l'Exploitation de la Mer, Plouzané, France, ${ }^{10}$ The Lyell Centre for Earth and Marine Science, Heriot-Watt \\ University, Edinburgh, United Kingdom, "1 Department of Marine Sciences-Tjärnö Marine Laboratory, University \\ of Gothenburg, Strömstad, Sweden, ${ }^{12}$ School of Aquatic and Fishery Sciences, Seattle, WA, United States, ${ }^{13}$ Monterey Bay \\ Aquarium Research Institute, Moss Landing, CA, United States, ${ }^{14}$ Department of Ocean Systems Sciences, NIOZ Royal \\ Netherlands Institute for Sea Research, Utrecht University, Den Burg, Netherlands
}

Cold-water coral (CWC) habitats dwell on continental shelves, slopes, seamounts, and ridge systems around the world's oceans from 50 to $4000 \mathrm{~m}$ depth, providing heterogeneous habitats which support a myriad of associated fauna. These highly diverse ecosystems are threatened by human stressors such as fishing activities, gas and oil exploitation, and climate change. Since their life-history traits such as long lifespan and slow growth rates make CWCs very vulnerable to potential threats, it is a foremost challenge to explore the viability of restoration actions to enhance and speed up their recovery. In contrast to terrestrial and shallow-water marine ecosystems, ecological restoration in deep marine environments has received minimal attention. This review, by means of a systematic literature search, aims to identify CWC restoration challenges, assess the most suitable techniques to restore them, and discuss future perspectives. Outcomes from the few restoration actions performed to date on CWCs, which have lasted between 1 to 4 years, provide evidence of the feasibility of coral transplantation and artificial reef deployments. Scientific efforts should focus on testing novel and creative restoration techniques, especially to scale up to the spatial and temporal scales of impacts. There is still a general lack of knowledge about the biological, ecological and habitat characteristics of CWC species exploration of which would aid the development of effective restoration measures. 
To ensure the long-term viability and success of any restoration action it is essential to include holistic and long-term monitoring programs, and to ideally combine active restoration with natural spontaneous regeneration (i.e., passive restoration) strategies such as the implementation of deep-sea marine protected areas (MPAs). We conclude that a combination of passive and active restoration approaches with involvement of local society would be the best optimal option to achieve and ensure CWC restoration success.

Keywords: deep-sea, human impacts, coral reefs, marine protected area, coral husbandry, challenges, review

\section{INTRODUCTION}

Over the past 50 years humans have changed ecosystems more rapidly and extensively than in any comparable historical period. This transformation of the planet has contributed to substantial net gains in human well-being and economic development, but at the same time has resulted in a substantial and largely irreversible loss in the diversity of life on Earth (Millennium Ecosystem Assessment, 2005; Cardinale et al., 2012; IPBES, 2019). Many ecosystems and their functioning have been impaired beyond critical points and are not able to return to their native states or previous developmental trajectories (Jackson et al., 1995; Jackson, 2001). Conservation measures are crucial for the preservation and recovery of natural and cultural heritage. However, the current pace and scale of global environmental degradation across a wide swath of ecosystems call for active ecological restoration measures, to aid the recovery of these ecosystems and the services they provide (Lotze et al., 2011; Gann et al., 2019; Duarte et al., 2020).

At present, the practice of ecological restoration - as part of a larger set of ecosystem management practices designed to conserve natural ecosystems - is receiving increasing attention worldwide. Ecological restoration has been recognized under different frameworks, and conventions (e.g., the UN Decade on Ecosystem Restoration, the UN Decade of Ocean Science for Sustainable Development and the Convention on Biological Diversity), as it offers the opportunity to counteract the anthropogenic damage that has already taken place (Falk et al., 2006). The Society for Ecological Restoration (SER), founded in 1983, established that ecological restoration actions aim to move a degraded ecosystem to a trajectory of recovery that allows the persistence of its component species, as well as the adaptation to local and global changes (Gann et al., 2018). Ecological restoration activities seek to accelerate the recovery of ecosystem structure and functioning relative to an appropriate reference model (the chosen endpoint of restoration).

However, the term "restoration" has always been surrounded by a certain ambiguity (Ounanian et al., 2018), and SER has re-evaluated and altered its definition several times in the last decade. The latest standard set by SER in 2019 established three different approaches to restoration that may be applied individually or in combination, as appropriate. We consider these approaches in this review: (1) Natural regeneration: this corresponds to so-called 'passive restoration.' It encompasses the removal of stressors through the creation of protected areas where the recovery of the biota arises from natural colonization, dispersal and other in situ process. (2) Assisted regeneration: once the source of degradation has been removed, this type of 'active restoration' necessitates direct human interventions that actively trigger the natural population growth capacity of biota. Interventions include removal of non-native species, installation of resources to prompt colonization, etc. (3) Reconstruction: when ecosystems have been severely damaged, this type of 'active restoration' calls not only for the removal of sources of degradation but also the improvement of the biotic and abiotic ecosystem condition. Here, direct human intervention is needed to reintroduce all, or a major proportion of the biota, which otherwise would not be able to regenerate or recolonize the area within a reasonable time frame.

Complete recovery of ecosystems is difficult to achieve (Jones et al., 2018), since all identified ecosystem attributes (e.g., physical environment, desirable species) should be reintegrated into a self-organizing system that most resembles the reference model (Gann et al., 2019). Emerging formulations of restoration use historical knowledge as a guide, rather than a template, accepting multiple potential ecosystem trajectories, recognizing the major importance of ecological processes over ecosystem structure and composition, and promoting the establishment of pragmatic goals to reflect human livelihood needs (Higgs et al., 2014). The three approaches to ecological restoration are part of a continuum of restorative activities that strive toward recovery of an ecosystem (McDonald et al., 2016; Aronson et al., 2017). It is beneficial to consider that some restorative actions (such as reducing human impacts) may not have as an ultimate goal, full recovery of an ecosystem at the time of implementation, but will contribute toward a more sustainable use of the ecosystem and facilitate future decisions toward restoration. In order to encourage this difficult task, the active restoration efforts often target key foundation species such as trees, kelps, or corals. These taxa often facilitate the re-establishment of associated species and succession processes that are crucial to restore the functioning of the ecosystems (Bruno et al., 2003).

In the specific case of marine ecosystems, most active ecological restoration actions have been performed in shallow waters, mainly focused on the restoration of salt marshes (Bakker et al., 2002; Hughes and Paramor, 2004; Laegdsgaard, 2006), tropical coral reefs (Rinkevich, 2005; Precht and Robbart, 2006; Young et al., 2012), oyster reefs (Babcock et al., 1998; Brumbaugh et al., 2006; Baggett et al., 2015), mangroves (Proffitt and Devlin, 2005; Bosire et al., 2008; Primavera and Esteban, 2008), seagrass meadows (Paling et al., 2009; van Katwijk et al., 2009, 2016) macroalgal forests (Verdura et al., 2018; Layton et al., 2020; 
Medrano et al., 2020) and temperate gorgonians (Weinberg, 1979; Linares et al., 2008; Fava et al., 2010). Recently, marine restoration reviews (Basconi et al., 2020; Duarte et al., 2020) reported high frequency of success, supporting the feasibility and potential of active restoration techniques, however, neglecting deeper habitats. Yet, primarily due to technical challenges and associated high cost in accessing the intermediate (from 5070 to $200 \mathrm{~m}$ depth) and deep-sea environments (below $200 \mathrm{~m}$ depth), active ecological restoration efforts on these ecosystems still remain scarce (Van Dover et al., 2014; Da Ros et al., 2019). Cold-water corals (CWCs) are often key habitat-forming species in this part of the ocean, generating complex three-dimensional structures that create hotspots of biodiversity over large areas, including CWC reefs and coral gardens (Roberts et al., 2009). They are increasingly affected by multiple stressors including fisheries with bottom-contact gears, offshore oil and gas activities, and climate change (Althaus et al., 2009; White et al., 2012; Clark et al., 2016; Morato et al., 2020). In the near future many CWCs will also be on the frontline of exposure to impacts from deep-sea mining (Levin et al., 2016; Gollner et al., 2017).

The present study synthesizes the latest information on CWC active restoration with the aim of advancing beyond the challenges of restoring CWC ecosystems and to create a new understanding of opportunities now available to undertake these activities. We first summarize the main biological and ecological features of CWC species (Section 2), their main drivers of degradation (Section 3), and their protection (Section 4). We then compile and discuss techniques used for actively restoring CWC habitats, highlight current challenges facing their restoration, and examine restoration costs and collaboration with industry (Section 5). Finally, we conclude by highlighting lessons learned from shallow-water restoration to move forward in active CWC ecological restoration (Section 6).

\section{COLD-WATER CORAL ECOSYSTEMS}

CWCs are cnidarians encompassing species from Scleractinia, Octocorallia, Antipatharia and Stylasteridae (ICES and HallSpencer, 2007; Roberts et al., 2009). Despite the high prevalence of tropical coral reefs at shallow depths, most coral species are found in the world's aphotic zone, in cold waters from 50 to $4000 \mathrm{~m}$ depth (Roberts et al., 2009; Bergmark and Jorgensen, 2014) on continental shelves, margins, seamounts, canyons and ridge systems (Freiwald and Roberts, 2005; Roberts et al., 2006, 2009; Cordes et al., 2016a). In those habitats, in addition to the six species of reef framework-forming scleractinian CWCs (Scleractinia), many other CWC species can form extensive coral gardens (Octocorallia, Antipatharia and Stylasterida) often mixed with solitary and/or reef framework-forming corals, under suitable conditions (e.g., appropriate substrate, water current and food supply). These CWC ecosystems increase habitat heterogeneity and support enhanced biological diversity and ecosystem functioning (Roberts et al., 2006, 2009; Cordes et al., 2008; Armstrong et al., 2014). The structures they create can alter current flow, food availability, and sediment resuspension, which provides niches, shelter and nursery grounds for an abundant and diverse associated fauna including economically valuable species, both within and in the immediate vicinity of their habitats (Costello et al., 2005; Henry and Roberts, 2007; Demopoulos et al., 2014). CWC ecosystems support unique species, providing benefits to adjacent fisheries through the spillover effect of eggs, larvae, juveniles and adults (D'Onghia et al., 2010; Corbera et al., 2019).

CWCs are mainly sustained by feeding on particulate organic matter and zooplankton, which they capture from the water (Kiriakoulakis et al., 2005; Dodds et al., 2009; Mueller et al., 2013a), although more recently, chemosynthesis has been suggested to provide an additional source of energy (Middelburg et al., 2015). Significantly higher levels of biogeochemical cycling, respiration and benthic-pelagic coupling processes take place in CWC ecosystems in comparison to the surrounding seafloor, enhancing the ecosystem functioning of the deep-sea biome (Wild et al., 2009; Burdett et al., 2014; Cathalot et al., 2015; Rovelli et al., 2015). CWC species are often slow-growing, with potentially long lifespans (Andrews et al., 2002; Roark et al., 2009; De Moura Neves, 2016), delayed sexual maturity and limited recruitment success (Roberts et al., 2009; Watling et al., 2011; Lacharité and Metaxas, 2013); thus, many species are expected to recover slowly after any disturbance. Two separate studies have shown that over a period of 8 to 10 years following the cessation of fishing activities with bottom-contact gears there was no natural recovery of impacted CWC communities, even at depths shallower than $1000 \mathrm{~m}$ (Althaus et al., 2009; Williams et al., 2010; Huvenne et al., 2016). It has been estimated that CWCs heavily impacted by the Deepwater Horizon oil spill (Gulf of Mexico, April 2010) could take up to three decades to visibly recover, and likely hundreds of years to grow back to their original size (Girard et al., 2018). According to their fragility, structural complexity, functional significance, and low recovery capability from impacts, many CWC ecosystems meet the criteria for Vulnerable Marine Ecosystems (VME; FAO, 2009a) and are listed in the OSPAR List of Threatened and/or Declining Species and Habitats (OSPAR, 2009, 2010). Thus, their conservation is internationally recognized as a high priority for the maintenance of marine biodiversity and the ecosystem services provided (Thurber et al., 2014; Cordes et al., 2016a).

\section{DRIVERS OF DEGRADATION}

The main threats for CWC ecosystems come from human maritime activities, such as fishing, hydrocarbon exploitation and the incipient mining activity, which have direct contact with the seabed causing an immediate impact on CWC communities (Ragnarsson et al., 2017; Miller et al., 2018). Fishing is one of the most extensive activities that interacts with the seabed and has gradually encroached into deeper waters (Roberts, 2002; Gross, 2015). Worldwide fishing impacts down to $1000 \mathrm{~m}$ depth are widespread, with almost all shelf and slopes areas being fished to some extent (Puig et al., 2012; Pham et al., 2014). Whilst the majority of trawling occurs on soft flat sediments, impacted areas also include CWC habitats (Hall-Spencer et al., 2002; Pham et al., 2014; Boavida et al., 2016; Huvenne et al., 2016; 
Ragnarsson et al., 2017; Buhl-Mortensen and Buhl-Mortensen, 2018) because of their role as important faunal nursery grounds for the surrounding fisheries (Baillon et al., 2012). Bottom trawling causes direct habitat degradation (Pusceddu et al., 2014; Rijnsdorp et al., 2016) as well as indirect effects including the resuspension of sediment plumes from the trawl track that can smother corals as they precipitate over the reefs (Ramirez-Llodra et al., 2011; Martín et al., 2014). Other bottom-contact fishing gears such as traps, longlines and trammel nets may also impact through the damage and removal of corals, as they are easily entangled in nets, overall contributing to the degradation of CWC communities (Wareham and Edinger, 2007; Durán Muñoz et al., 2011; Sampaio et al., 2012). Impacts from the fishing industry also include those caused by lost fishing gears and fishing related litter in which corals can get entangled (Bo et al., 2014; Buhl-Mortensen and Buhl-Mortensen, 2018). Operations in offshore oil and gas industries also produce large contaminated cuttings piles and sediment plumes that can impact CWCs in a variety of ways (Cordes et al., 2016b). While adult colonies of the CWC Lophelia pertusa can generally withstand a degree of discharged cuttings without significant ecophysiological impacts (Larsson et al., 2013; Baussant et al., 2018) the dispersive larval phase of this CWC is highly susceptible to mortality from sediment loads (Järnegren et al., 2017). Moreover, accidental oil spills can profoundly affect CWCs, with impacts from the molecular to the ecosystem scale (White et al., 2012; Fisher et al., 2014; DeLeo et al., 2016; Joye et al., 2016; Weinnig et al., 2020). Additionally, CWC ecosystems are expected also to be exposed to the future impacts of deep-sea mining activities (Christiansen et al., 2019).

Global change will exacerbate these stressors (e.g., ocean acidification and increase in temperature, Weinnig et al., 2020) and will, within the coming century, significantly reduce suitable habitats for CWCs (Sweetman et al., 2017; Morato et al., 2020; Puerta et al., 2020). By the year 2100, projections indicate that about $70 \%$ of current CWC reef locations will become undersaturated with respect to aragonite, thus exposing the majority of presently existing reefs to an environment that favors carbonate dissolution, likely altering their global distribution and abundance (Guinotte et al., 2006). Although existing evidence suggests that some scleractinian corals can persist in undersaturated waters (Thresher et al., 2011; Movilla et al., 2014; Baco et al., 2017; Gómez et al., 2018), the metabolic rates of $\mathrm{CWC}$ species could be altered due to reallocation of energy reserves, reducing their fitness (Hennige et al., 2015; Georgian et al., 2016; Gori et al., 2016). Additionally, rise of seawater temperature, even in deep-sea environments (Purkey and Johnson, 2010), and decline in $\mathrm{O}_{2}$ concentrations together with reduced flux of organic matter to seafloor (Danovaro et al., 2017; Sweetman et al., 2017) can significantly impact CWCs by directly affecting food supply, growth, survival and recruitment rates (Danovaro et al., 2017).

\section{PROTECTING CWC ECOSYSTEMS}

International agreements and directives supporting the protection of CWC ecosystems are increasing worldwide
(Armstrong et al., 2014). Fishing closures and protected areas are the main instruments for the current conservation of deep-sea ecosystems (Harter et al., 2009; Huvenne et al., 2016), while Marine Spatial Planning with ecosystem-based approach (EB-MSP) and Other Effective Conservation Measures (OEC) have been recently highlighted as key tools for balancing socioeconomic and environmental objectives in a comprehensive marine conservation approach (Shabtay et al., 2019; Manea et al., 2020). To date, a number of countries have created specific Marine Protected Areas (MPAs) for CWC ecosystems: the Darwin Mounds and Hatton Bank (United Kingdom), the Oculina Bank Marine Protected Area, the Davidson Seamount and Aleutian Gorgonian Gardens (United States), the Northeast Channel Coral Conservation Area (Canada), and the Commonwealth Marine Reserve (Australia), amongst others (DeVogelaere et al., 2005; George et al., 2007; Durán Muñoz et al., 2009; Harter et al., 2009; Huvenne et al., 2016; Althaus et al., 2017; Bennecke and Metaxas, 2017). Harter et al. (2009) were the first to quantify positive effects of a deep-sea MPA (Oculina Bank Marine Protected Area). Moreover, high coral abundances and the presence of some large colonies and recruits pointed to a coral population recovery after 12 years following the closure of the Northeast Channel Coral Conservation Area to fishing (Bennecke and Metaxas, 2017). Likewise, after being a traditional fishery area, the North-western Hawaiian Ridge and Emperor Seamounts have been protected for 30 years. After this period, evidence for coral re-growth and greater abundances of benthic megafauna were detected (Baco et al., 2019). In some cases, protection alone is however not always successful. For instance, in the Eastern Darwin Mounds (United Kingdom), very little re-growth and no coral re-colonization have been detected after 8 years of fishing closure (Huvenne et al., 2016). Similarly, CWC communities in New Zealand seamounts did not recover after 15 years from cession of trawling (Clark et al., 2019). Both examples highlighted the low resilience and slow natural recovery capability of CWC ecosystems.

\section{ACTIVE ECOLOGICAL RESTORATION OF CWC ECOSYSTEMS}

To initiate or expedite recovery, it is highly desirable to actively improve the natural recovery (Dayton, 2003) by means of ecological restoration actions (Rinkevich, 2005). Ecological restoration is an attempt to return a damaged system to an ecological state that is within some acceptable limits relative to a less disturbed system, to recover a natural range of ecosystem structure and dynamics (Falk et al., 2006). Today, the practice of ecological restoration is receiving immense attention because it offers the hope of recovery from much of the environmental damage inflicted by misuse or mismanagement of natural resources (Falk et al., 2006).

To better understand the current state of the art in CWC active ecological restoration, a systematic literature search was conducted using the biographic database Web of Science in August 2020. Specifically, an advanced search was confined by the combination of the terms "restore*," "transplant", "protect*," "conserve*", and "marine protected area" with a second term 
related to the coral taxa, habitats and target of restoration: "deep sea," "cold-water coral," "deep sea coral*," "deep sea octocoral*," deep sea scleractinian*", and "deep sea gorgonian*." Published articles up to August 2020, including scientific papers, book chapters, reports and technical summaries were screened and included in the analysis if they contained information regarding restoration of CWC communities and ecosystems. Reference lists of articles, including reviews identified in the literature search, were checked for additional studies.

A total of 81 scientific publications contained data related to $\mathrm{CWC}$ restoration, including passive and active restoration approaches. The first studies focusing on the protection and restoration of CWCs were published at the beginning of the 20th century and have been gradually increasing to date (Figure 1). Given the international concern for the conservation of deep-sea ecosystems (Davies et al., 2007) and the establishment of deep-sea MPAs, passive restoration studies focused on the protection and management of CWCs constitute most of the published papers $(48.2 \%)$. In contrast, studies on active restoration initiatives (16.0\%), complementary studies with implications for active restoration $(25.9 \%)$ and reviews with theoretical considerations (9.9\%) have been less frequently published, appearing mainly in the last decade, and providing evidence that little work has been done so far and that CWC restoration is a very recent research line (Figure 1). Only 13 publications focus on CWC active restoration initiatives (Table 1) since 2001, contrasting with the 221 scientific publications for the case of active restoration of coral ecosystems in shallower waters since 1980 (Boström-Einarsson et al., 2020). Complementary studies encompassed scientific publications exploring natural recovery of CWCs, larval dispersion and recruitment, deep-sea connectivity and in situ coral growth monitoring, with implications for actively restoring CWC ecosystems. All of these, together with theoretical consideration studies, are crucial for adding scientific and technical knowledge to support active restoration actions and improve their success.

Following previous experience in shallow-water ecosystems, scientific efforts to restore CWCs (including protection measures and active restoration) were more focused on scleractinian species and CWC reefs (45.7\%) rather than on octocoral species and CWC gardens (17.2\%) (Figure 2). There were also publications encompassing both taxa (11.1\%) or CWCs in general, without specifying the taxon involved (25.9\%). The CWC scleractinian L. pertusa stands out as the most commonly studied coral species appearing in $29.6 \%$ of CWC restoration publications (Figure 2).

\section{Techniques for Actively Restoring CWC Ecosystems}

There are currently only a few active restoration actions carried out worldwide, all of them located in the northern hemisphere (13 scientific publications for 7 case studies in 6 different countries): the Säcken Reef in Sweden, the Sur Ridge in California, CWC Reefs in the Gulf of Mexico and south eastern off Florida, and CWC gardens in the Western Mediterranean and Azores (Figure 3 and Table 1). Learning

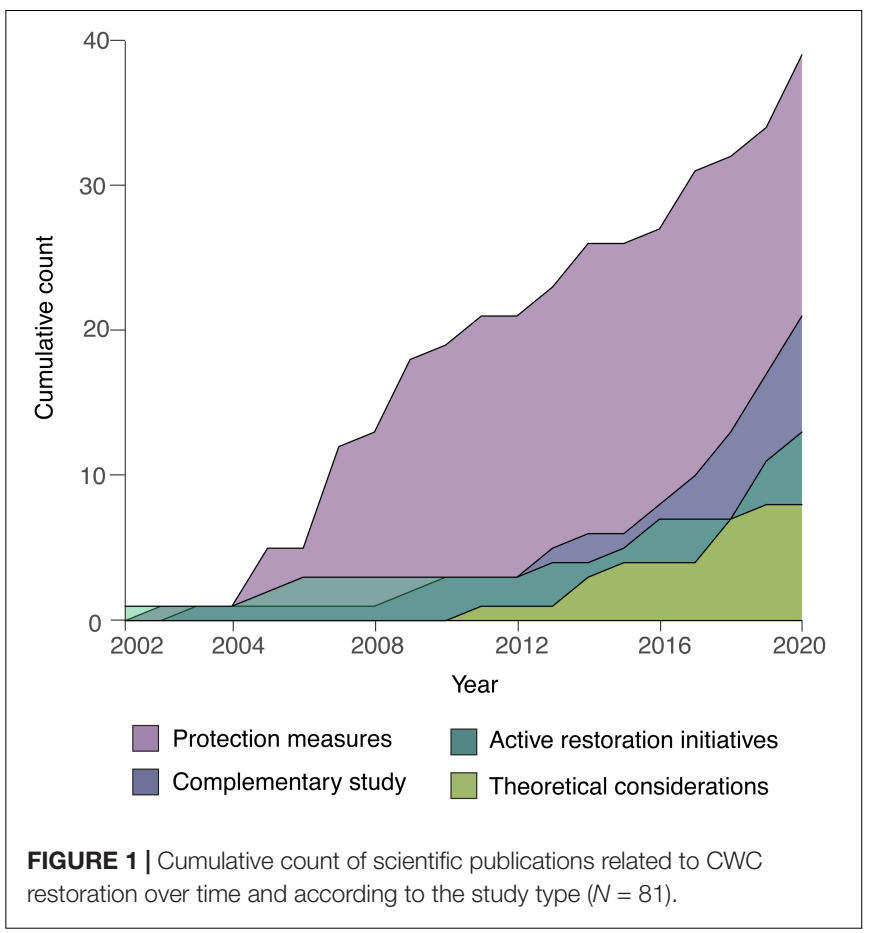

from experience in shallow coral restoration, the most used techniques for active CWC restoration are transplantation techniques (52\%) and the use of artificial structures (44\%) (Figure 4). Transplantation studies were focused on testing methods to attach CWC fragments to natural or artificial substrates. Studies with artificial structures encompassed the deployment or the decommissioning of artificial structures such as obsolete offshore oil and gas structures and collectors, for CWC larval recruitment. Mineral accretion through electrolysis (Biorock ${ }^{\mathrm{TM}}$ ), another restoration technique first developed for restoring shallow coral reefs, was tested in laboratory conditions with promising results as a suitable method for CWCs (Strömberg et al., 2010).

\section{Fragment Transplantation}

First attempts of active CWC restoration emerged in the early 21 st century, targeted on the CWC reef forming species Oculina varicosa (United States, Florida; Koenig, 2001; Brooke et al., 2006) and L. pertusa (Sweden; Dahl et al., 2012; Jonsson et al., 2015; Strömberg, 2016). These actions were based on transplantation of coral fragments from a healthy donor reef to a degraded one, using ROVs. Because of the difficulties associated with the in situ manipulation of coral fragments using ROVs, transplants were attached to artificial structures (concrete modules or racks), and then deployed at 70-100 $\mathrm{m}$ depth in impaired areas. After more than 2 years, transplanted coral fragments showed high survival $(>76 \%)$ and growth, with associated fauna being reestablished, but there was little evidence of new larval settlement or coral recruitment (Brooke et al., 2006; Dahl et al., 2012; Jonsson et al., 2015).

Active restoration of CWC gardens has been attempted only recently by evaluating the feasibility of coral transplantation 
TABLE 1 | Active restoration initiatives carried out to date focused on CWC habitats.

\begin{tabular}{|c|c|c|c|c|c|c|}
\hline Locality & $\begin{array}{l}\text { Restoration } \\
\text { technique }\end{array}$ & Restored Taxa & Depth (m) & $\begin{array}{l}\text { Duration time } \\
\text { (years) }\end{array}$ & Results & References \\
\hline SE Florida & $\begin{array}{l}\text { Transplantations on } \\
\text { artifical structures }\end{array}$ & Oculina varicosa & $70-100$ & $4-8$ & $\begin{array}{l}\text { Mean survival rate } 50-60 \% \text {, } \\
\text { Larval recruitment episodic } \\
\text { Fish abundance enhanced }\end{array}$ & $\begin{array}{l}\text { Koenig, 2001; } \\
\text { Brooke et al., } 2006\end{array}$ \\
\hline Gulf of Mexico & $\begin{array}{l}\text { Deployment of artificial } \\
\text { structures }\end{array}$ & Coral species & $21-400$ & $30-34$ & $\begin{array}{l}\text { Attachment of corals and other } \\
\text { sessile invertebrates }\end{array}$ & $\begin{array}{l}\text { Kaiser and Pulsipher, } \\
\text { 2005; Kaiser et al., } \\
2020\end{array}$ \\
\hline Sweden & $\begin{array}{l}\text { Transplantation on } \\
\text { artifical structures }\end{array}$ & Lophelia pertusa & $82-87$ & $3-4$ & $\begin{array}{l}\text { Mean survival rate of } 76 \% \\
\text { Mean size increase of } 39 \%\end{array}$ & $\begin{array}{l}\text { Dahl et al., 2012; } \\
\text { Jonsson et al., } 2015\end{array}$ \\
\hline Sweden & $\begin{array}{l}\text { Transplantation on } \\
\text { artifical structures }\end{array}$ & Lophelia pertusa & $75-90$ & Not specified & Still not recorded & Strömberg, 2016 \\
\hline California & Transplantation & $\begin{array}{l}\text { Corallium sp., Lillipathes sp., Swiftia } \\
\text { kofoidi, Keratoisis sp., Isidella } \\
\text { tentaculum, Paragorgia arborea, } \\
\text { and Sibogagorgia cauliflora }\end{array}$ & $800-1300$ & 1 & $\begin{array}{l}\text { Mean survival rate of } 52 \% \\
\text { After } 3 \text { years coral survival differed } \\
\text { among species }(0 \%-100 \%)\end{array}$ & $\begin{array}{l}\text { MBARI, 2016; } \\
\text { Boch et al., 2019; } \\
\text { Boch et al., } 2020\end{array}$ \\
\hline $\begin{array}{l}\text { NW } \\
\text { Mediterranean }\end{array}$ & $\begin{array}{l}\text { Transplantatation on } \\
\text { artifical structures }\end{array}$ & Eunicella cavolini & 85 & 1 & $\begin{array}{l}\text { Mean survival rate of } 87.5 \% \text {. } \\
\text { Feasibility of large-scale and } \\
\text { low-cost active restoration method }\end{array}$ & $\begin{array}{l}\text { Montseny et al., 2019; } \\
\text { Montseny et al., } 2020\end{array}$ \\
\hline Azores & $\begin{array}{l}\text { Transplantation on } \\
\text { artifical structures }\end{array}$ & $\begin{array}{c}\text { Dentomuricea aff. Meteor, Viminella } \\
\text { flagellum, Callogorgia verticillata, } \\
\text { Paracalyptrophora josephinae }\end{array}$ & 230 & 1 & $\begin{array}{c}\text { Coral survival differed among } \\
\text { species (15-100\% survival rates) }\end{array}$ & $\begin{array}{l}\text { Carreiro-Silva et al., } \\
\text { submitted }\end{array}$ \\
\hline
\end{tabular}

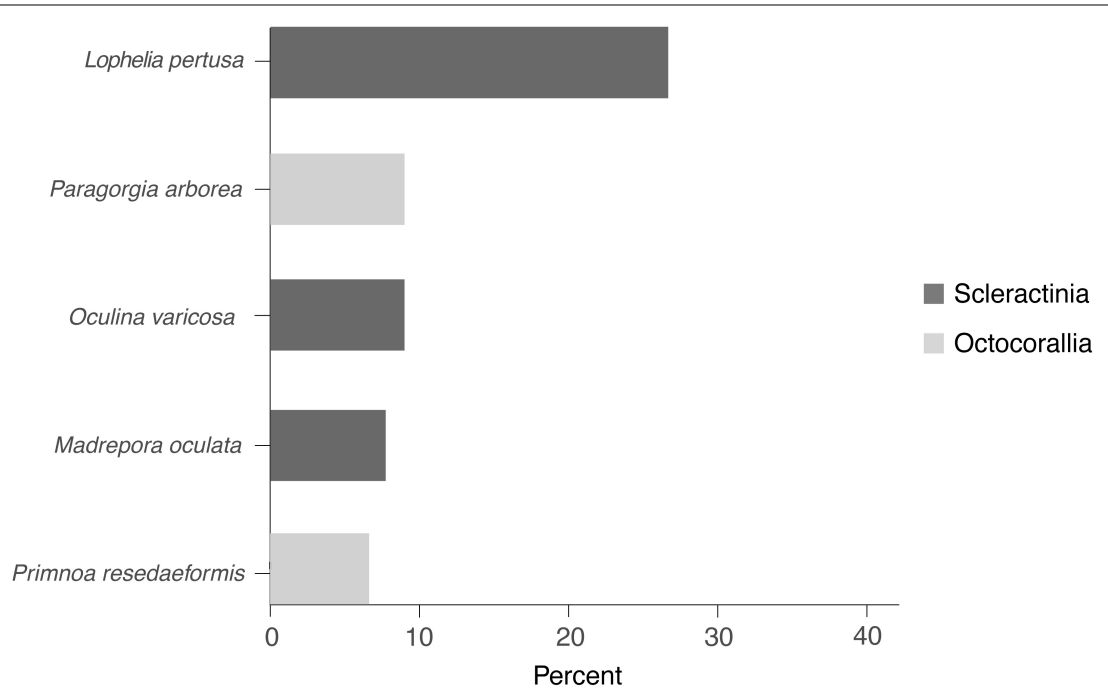

FIGURE 2 | Five most studied coral species in CWC restoration publications $(N=81)$.

techniques previously developed for tropical (Yap, 2000; Lindahl, 2003; Forrester et al., 2011) and temperate gorgonians (Weinberg, 1979; Linares et al., 2008; Fava et al., 2010). Pilot restoration actions focused on CWC gardens were tested at $200 \mathrm{~m}$ depth on the Condor Seamount (Azores Archipelago, Supplementary Box 1) and at $85 \mathrm{~m}$ depth in the Cap de Creus continental shelf (Western Mediterranean, Supplementary Box 2). During the same period, Boch et al. (2019) carried out a multiple species translocation study with seven different CWCs, including gorgonians, at 800-1300 m depth on the Sur Ridge within the Monterey Bay National Marine Sanctuary (United States) (Supplementary Box 3).
Transplantation of coral fragments may not be easily applicable to all CWC species. Handling, collecting, transporting and maintaining some CWCs in aquaria facilities before returning them to their natural habitat can be an issue. The stress suffered by corals during collection, such as thermal changes, and the complexity of replicating their natural environment in the laboratory, can compromise the survival of corals in aquaria (Orejas et al., 2019). In a first attempt to restore CWC gardens at the Sur Ridge, none of five coral fragments (Keratoisis sp., Paragorgia arborea) that were maintained overnight in aquaria prior to transplantation, or five fragments transplanted in situ (i.e., not brought to the surface) were found alive after 1 year 


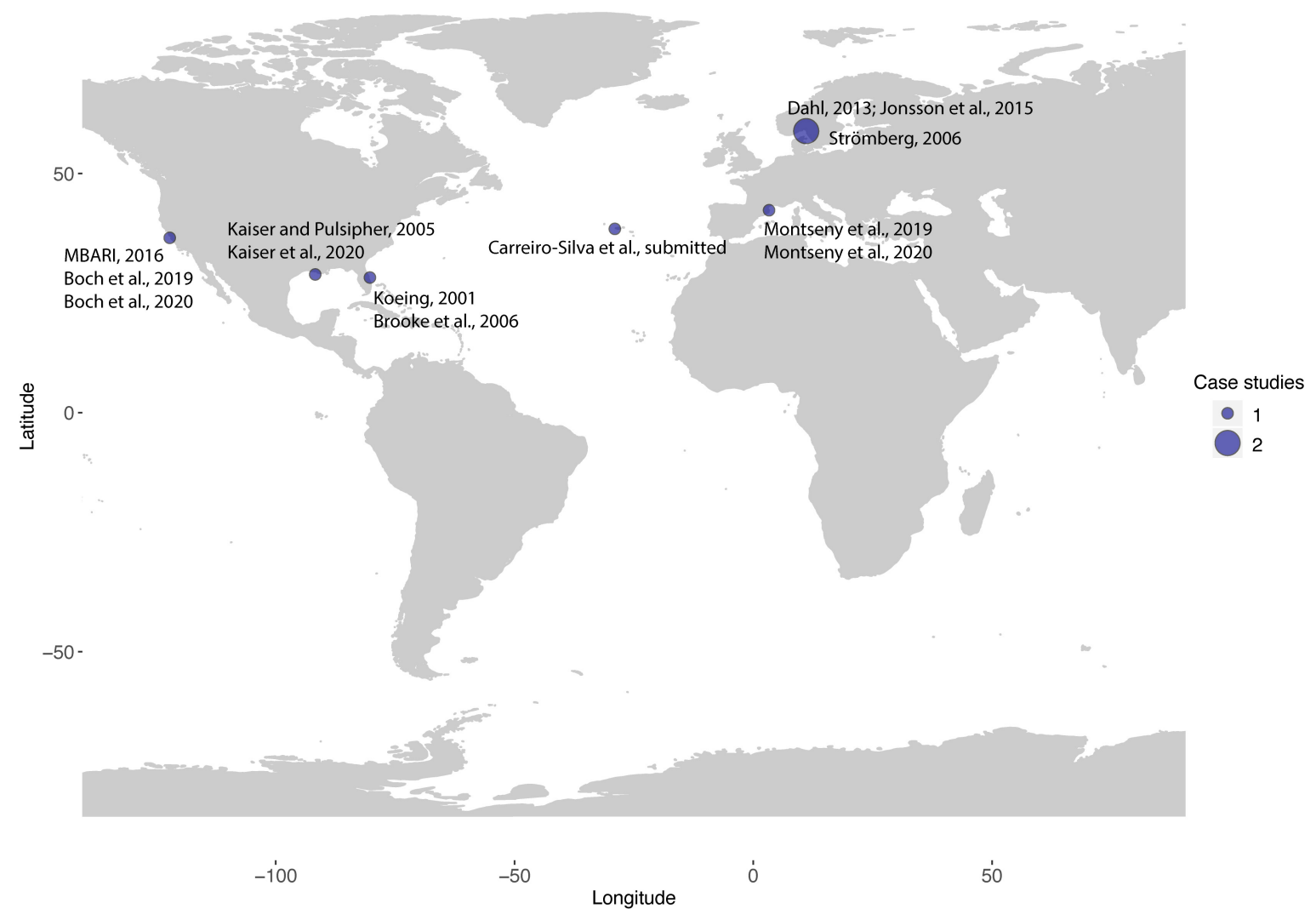

FIGURE 3 | Overview map of the worldwide locations of active restoration projects focused on CWC ecosystems. Circle size corresponds to the number of case studies in each site, up to August 2020 ( $N=7)$.

from their reintroduction (MBARI, 2016). This was overcome, in part by avoiding long-term maintenance of corals in aquaria and by also improving the attachment of coral fragments to transplantation structures on board the ship at sea, resulting in a mean coral survival of $52 \%$ after 1 year (Boch et al., 2019). The main advantage of transplanting coral fragments (usually with branching forms) is the faster recovery of the three-dimensional structure of coral populations, facilitating the recovery of their habitat-forming functions for a large number of associated species (Horoszowski-Fridman et al., 2015; Geist and Hawkins, 2016). Conversely, the main disadvantage of fragment translocation is the requirement for coral fragment collections that usually impact healthy coral assemblages. Moreover, by using large transplants (which suffer less natural mortality after transplantation, Brooke et al., 2006), more material is required from the donor site.

One partial solution developed in both the Mediterranean Sea and Azores was to work with local fishers using bycatch corals (Supplementary Boxes 1, 2). These pilot studies showed that not all CWC corals are able to survive and recover from the impacts of being accidentally fished, however some species do and easily recover if they are kept in appropriate aquaria conditions before restoration (Montseny et al., 2019). By using bycatch corals, the fishing impact on the natural populations is also mitigated, as bycatch corals are being returned to the environment and at least a small part of this loss is reversed. The overall cost of the restoration action is also reduced, with no need for expensive technology for coral collection. Furthermore, since fishing activity generally covers a wide spatial extent, it could favor an increase in the genetic diversity of transplanted coral fragments, which would provide more potential for habitat shelfsupport. However, this requires active, deep-water fishing activity near or around the area designated for restoration and fishers willing to collaborate, which is not always the case.

\section{Artificial Structures}

Colonization of artificial structures is determined by the arrival of larvae and propagules and the subsequent local survival of adults (Dannheim et al., 2018). New recruits that will settle on artificial structures will be probably better adapted to the new conditions at the site. The capability of L. pertusa larvae to disperse over long distances and to potentially survive for a long time confirms the potential of this CWC to colonize artificial structures (Strömberg and Larsson, 2017; Henry et al., 2018). The type of structure, age, and depth of artificial reefs used all influence colony density and growth as observed in L. pertusa on 10 artificial structures in the Northern Gulf of Mexico (Larcom et al., 2014).

Finding the best larval settlement surface is a first key step for the use of artificial structures. Complex substrates have been shown to promote higher colonization by deep-sea 


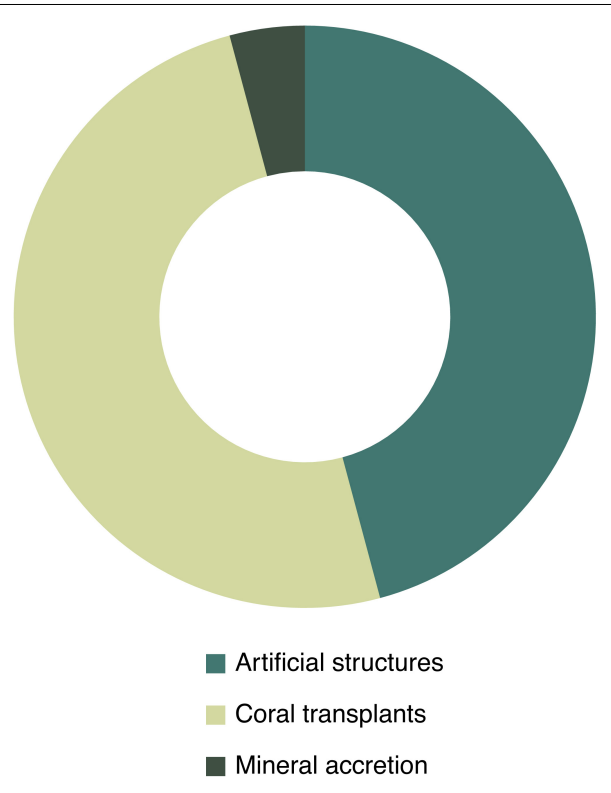

FIGURE 4 | Active restoration techniques studied in CWC restoration publications $(N=25)$.

benthic invertebrates than simple substrates (Girard et al., 2016). Likewise, new larval recruitment of L. pertusa observed close to some restored sites has mainly been on dead coral skeleton with a remaining elevated $3 \mathrm{D}$ structural complexity, while no recruitment has been observed on other former CWC reef sites in the area where only unconsolidated coral rubble remains (authors unpublished data).

However, in situ larval settlement experiments targeting CWCs have had mixed results. While a study found high recruitment rates for Primnoa resedaeformis on artificial substrate deployed for 4 years in the Northeast Channel Coral Conservation area off eastern Canada, very few Paragorgia arborea recruits were recovered on these same substrates (Lacharité and Metaxas, 2013). Differences in the number of recruits of the two species could be due to differences in the reproductive strategies (broadcast spawning vs brooding). Recent work with larvae of $L$. pertusa has shown that they probably prefer cryptic spaces when settling (Strömberg et al., 2019), indicating that settling substrates must be specific to target species. Moreover, very little or no coral recruitment was observed for $O$. varicosa after 5 years from the deployment of concrete modules in south eastern off Florida (Brooke et al., 2006). The varying recruitment successes of these studies highlight the importance of increasing the knowledge on CWC larval ecology, especially about factors affecting dispersal, settlement and recruitment success. The more that is known for larvae of a species, the better the artificial substrates can be modeled to promote its settlement and recruitment. This approach is being used in the recently started CWC restoration project LIFE Lophelia (coral reef habitat restoration in Kosterhavet, Sweden) (Supplementary Box 4). Obsolete oil and gas industry platforms represent de facto artificial substrate for natural and active recolonization of corals and other epifaunal species (Macreadie et al., 2011; Bergmark and Jorgensen, 2014; Larcom et al., 2014). Part of these structures may be left in situ as part of the decommissioning process, e.g., as in the North Sea (Henry et al., 2018) where platforms have been in place for $>40$ years, toppled in situ or transported to locations where coral restoration is required and where their disposal makes ecological sense (Macreadie et al., 2011). Through the Louisiana and Texas Rigsto-Reef Programs, established respectively in 1986 and 1991, a total of 97 artificial platforms had been transported to deep locations ( $>120 \mathrm{~m}$ ) in the Gulf of Mexico as of 2008 (Kaiser et al., 2020). Shortly after offshore structures were installed, corals and others sessile invertebrates such as oysters, sponges, hydroids, mussels and barnacles attached to the structures, attracting a number of mobile invertebrates and fish species, forming highly complex communities (Kaiser and Pulsipher, 2005; Kaiser et al., 2020). However, it should be noted that the potential use of decommissioned structures of the offshore oil and gas industry as artificial structures to prompt CWC reef formation is still controversial. There are scenarios where unexpected recolonization of man-made structures may assist in restoring ecosystems at a faster rate than would occur through natural recolonization events (Supplementary Box 5), but at the same time, a range of factors need to be considered including health and safety, technology readiness, social factors, and the spread of invasive species (Fowler et al., 2018). Indeed, invasive species of Tubastrea have long since colonized rigs-to-reefs structures in Gulf of Mexico (Sammarco et al., 2010) and operational platforms in Brazil.

\section{Mineral Accretion Through Electrolysis}

Mineral accretion through electrolysis techniques was developed by Hilbertz and Goreau (1996) and has been widely used in tropical shallow coral reefs active restoration actions to enhance the growth of coral transplants. During the active phase of the mineral accretion, when the cathode is getting a trickle current and accretion of aragonite is ongoing, coral transplants bud and branch more frequently. The accreted material has the same composition of minerals as the coral skeleton itself (i.e., calcium carbonate in the form of aragonite). Moreover, when the electricity is turned off the accreted material attracts coral larval recruits (Kihara et al., 2013). Applied to the CWC L. pertusa, mineral accretion through electrolysis significantly increased polyp budding frequency and growth rates. However, the optimal current density level was found to be considerably lower than levels used in previous studies with shallow coral species. This highlighted the method to be suitable for at least some CWC, after the assessment of the optimal current density level to be used (Strömberg et al., 2010).

\section{Challenges in Actively Restoring CWC Ecosystems Performing Active Restoration}

The main technical constraints in CWC restoration are the difficulties and associated costs in accessing remote deep-sea ecosystems (Van Dover et al., 2014). Technical diving with mixed gases can allow divers to access only relatively shallow 
depths (50-150 m) (Pyle and Copus, 2019) across the CWC bathymetric distribution (50-4000 $\mathrm{m}$ depth) (Freiwald and Roberts, 2005; Roberts et al., 2006, 2009). In theory, divers could easily transplant coral fragments on natural substrate following the same techniques used for shallow coral reefs (Rinkevich, 1995; Edwards and Gomez, 2007; Edwards et al., 2010). However, the working-time for deep technical diving is extremely limited, and the risks associated with the activity are high (Fock and Millar, 2008; Sayer et al., 2008; Pyle and Copus, 2019). As a consequence, a long overall operational time will be needed to perform a restoration action by means of technical diving, and advanced safety measures (continuous access to decompression chambers and medical personnel) would be necessary to support the activity at all times, thereby increasing costs. In contrast, ROVs are the main and most widespread alternative for access to the deep sea (Van Dover et al., 2014). ROVs allow for long bottom-working time and significantly reduce risks to human life. However, technological hurdles involved in manipulating corals in the deep sea are still significant (Thresher et al., 2015). In particular, the main technical challenge is the dexterity of an ROV's manipulator arms to attach fragile coral fragments to rocky substrates using reattachment materials such as epoxy resins. This is a difficult task to be performed with fragments of stony corals, but even more so with gorgonians or black corals, whose flexible axial skeletons may be moved by seabed currents while the reattachment material hardens, compromising the stability of the transplanted fragments (Collier et al., 2007). Thus, gorgonian and black coral fragments need to be first fixed with epoxy resin to a small sturdy base in aquaria with no water flow and subsequently be transplanted in the field once the resin has dried (Clark and Edwards, 1995; Jaap, 2000; Young et al., 2012). In this sense, as for shallower waters, if the gorgonian or the black coral remains attached to a piece of dislodged substrate, it can be more easily reattached using the same methods as for stony corals (Collier et al., 2007). The employment of Autonomous Underwater Vehicles (AUVs) to autonomously transplant coral fragments to natural substrata in the deep sea is still in the distant future and will require substantial technological development. The possibility for an AUV to move and automatically locate and place small structures or modules supporting transplanted coral fragments on the seabed, could be a first step in this direction. Promising advances are being made on the capability of AUVs to autonomously locate and manipulate objects (Galloway et al., 2016; Mura et al., 2018; Sahoo et al., 2019). In addition, machine-learning approaches are helping to advance the automated detection of suitable sites for CWC active restoration actions (Henry et al., 2016).

\section{Selecting Donor Sites}

The selection of donor populations, from where to collect fragments to be used in any active restoration action, is also of increased difficulty for CWCs compared to shallow coral species, owing to still quite limited knowledge of CWC distribution and connectivity in the deep sea. Even less information is available on CWC population structure and dynamics, which is basic information required to select donor populations and to evaluate potential collection impacts (Edwards et al., 2010). In the absence of this knowledge, donor sites should be selected as close to the restored sites as possible since these would have a higher probability of containing colonies adapted to the environmental and ecological conditions of the area.

\section{Life-History Traits of CWCs}

Longevity is strongly and positively correlated with maximum depth of occurrence in marine sessile species (Montero-Serra et al., 2018). Hence, it is not surprising that some CWC species live for hundreds to thousands of years (Roark et al., 2009; Bennecke et al., 2016). Slow growth rates have been reported for both stony corals (Reed, 1981; Rogers, 1999; Freiwald et al., 2004; Orejas et al., 2008, 2011; Lartaud et al., 2014) and gorgonians (Andrews et al., 2002; Risk et al., 2002; Sherwood and Edinger, 2009; Watling et al., 2011; Bennecke et al., 2016). Growth rates in stony corals ranges from $0.3-1.8 \mathrm{~cm} \mathrm{yr}^{-1}$ in Madrepora oculata, $0.4-1.1 \mathrm{~cm} \mathrm{yr}^{-1}$ in L. pertusa, and $1.1-1.6 \mathrm{~cm} \mathrm{yr}^{-1}$ in O. varicosa (Orejas et al., 2008, 2011; Lartaud et al., 2014). Slightly higher growth rates were measured in cold-water gorgonians, ranging from $1.5-4.1 \mathrm{~cm} \mathrm{yr}^{-1}$ in $P$. resedaefromis, $1.6-4.0 \mathrm{~cm}$ $\mathrm{yr}^{-1}$ in $P$. arborea and 0.14 to $2.5 \mathrm{~cm} \mathrm{yr}^{-1}$ in Paramuricea spp. (Andrews et al., 2002; Buhl-Mortensen and Buhl-Mortensen, 2005; Sherwood and Edinger, 2009; Bennecke et al., 2016; Girard et al., 2019), with a general trend of exponentially decreasing growth rates with increasing colony size (Bennecke et al., 2016), and no increase in size for the largest colonies (Buhl-Mortensen et al., 2005; Watanabe et al., 2009; Bennecke et al., 2016). Overall, the range of such growth rates are a magnitude lower than observed for tropical shallow-water corals (Buddemeier and Kinzie, 1976; Bongiorni et al., 2003; De'ath et al., 2009). For this reason, CWC habitats are generally considered to have low recovery potential, which does not offer an effective short-term restoration solution (Bekkby et al., 2020). Long time spans (tens of years) will be required for transplanted CWC fragments to grow up to medium sized colonies, and even longer to grow up to fully functioning reef habitats.

Little is known about the reproductive biology of most CWCs, with some information available for the stony corals L. pertusa, M. oculata, O. varicosa, Enallopsammia rostrata, Solenosmilia variabilis and Goniocorella dumosa (Brooke and Young, 2003; Burgess and Babcock, 2005; Waller, 2005), and a number of coldwater gorgonians (Cordes et al., 2001; Orejas et al., 2007; Mercier and Hamel, 2011; Watling et al., 2011). While the knowledge is quite extensive considering fecundity, our understanding of dispersal processes and population connectivity is still hampered by the lack of knowledge about other reproductive traits (Watling et al., 2011). Factors such, as sexual condition (gonochorism or hermaphroditism), reproductive mode (broadcast spawning, internal or surface brooding), reproductive timing (continuous, periodic or seasonal reproduction) as well as larval ecology strongly affect dispersal potential (Waller, 2005; Treml et al., 2015; Reynaud and Ferrier-Pagès, 2019). When information on larval ecology and behavior becomes available, it can be of profound value to improve the predictions of larval dispersal (Fox et al., 2016; Strömberg and Larsson, 2017; Henry et al., 2018). Likewise, information on genetic population structure in CWCs is limited (Watling et al., 2011). This limited available knowledge 
on both CWC reproductive ecology and genetic connectivity significantly precludes or hinders proper spatial planning for CWC conservation (Cudney-Bueno et al., 2009), as well as the identification of priority locations for restoration actions.

\section{Limited Knowledge on Species Interactions}

As habitat-forming ecosystem engineers (Jones et al., 1994), CWCs create physical structures that enhance space, resources, and refuges for hundreds of associated species across trophic levels (Henry and Roberts, 2007; Buhl-Mortensen et al., 2010), facilitating the coexistence of species in highly diverse communities (Bruno and Bertness, 2001; Stachowicz, 2001). Consequently, transplanting coral fragments into impacted environments will provide habitats for other species, facilitate their return and re-establishment, and ultimately aid ecosystem recovery (Abelson, 2006; Halpern et al., 2007). However, very limited information is available on intra- and interspecies interactions, including predation, competition, symbiosis and facilitation processes in CWC ecosystems (Buhl-Mortensen and Buhl-Mortensen, 2004). These interactions may significantly impact the success of CWC active restoration actions. One example of the importance of species interactions is the four-fold enhanced calcification rates measured in L. pertusa when living in association with the polychete Eunice norvegica (Mueller et al., 2013b).

Density dependence in population dynamics may act as a negative force (inducing density-dependent mortality), but minimum densities are also necessary for population persistence or growth (Halpern et al., 2007). Positive population-level interactions include minimum population sizes (avoiding Allee effects) and conspecific cues that enhance recruitment and survival of juveniles (Halpern et al., 2007). This is extremely important for corals, as density may control reproductive success and feeding efficiency (Levitan, 1991; Wildish and Kristmanson, 1997). Moreover, interspecific interactions may result in indirect facilitation processes through trophic cascades (Halpern et al., 2007). In the case of CWCs, recent research has highlighted a key role of sponges in transferring energy and nutrients to higher trophic levels in the community by transforming dissolved organic matter into particulate organic matter (DOM to POM) (Rix et al., 2016). The presence of a trophic 'sponge loop' contributes to high levels of biogeochemical cycling enabling CWC reefs to develop in deep-sea energy-limited environments (Burdett et al., 2014; Cathalot et al., 2015; Rix et al., 2016). Overall, positive interactions have been recognized as important factors shaping population and community structure (Stachowicz, 2001; Bruno et al., 2003), and should be considered in ecological restoration actions to achieve the most effective results, accelerating recovery while reducing restoration times (Bruno and Bertness, 2001; Halpern et al., 2007). In this sense, multispecific restoration actions (e.g., including corals and sponges) may be a significant step forward for the successful recovery of functional CWC communities.

\section{Monitoring the Restoration Actions}

The success of most active coral restoration actions is mainly evaluated in terms of transplant survival. In tropical shallow coral reefs, highly successful restoration entails survival of more than $85 \%$ of restored corals, while failure occurs if less than $10 \%$ of restored corals survived after 5 years (Bayraktarov et al., 2016). However, beyond survival of restored organisms, there is active discussion to define appropriate metrics to properly evaluate restoration success (Fonesca et al., 2002; Elliott et al., 2007). Indeed, success of ecological restoration should be measured in terms of recovery of ecosystem function after the restoration effort, monitoring recovery trajectories and comparing with reference control sites (Kaly and Jones, 1998; Ruiz-Jaen and Mitchell Aide, 2005; Bayraktarov et al., 2016). Monitoring must be standardized, holistic, and linked to the objectives/goals set at the beginning of the restoration project. Thus, biological, ecological and physical assessments should measure not only the survival of transplanted organisms, but also changes in overall population and community structure, ecosystem functioning and changes in key abiotic factors. It is crucial to establish realistic restoration objectives in order to not fail in the evaluation of success, which could reduce public, academic, charitable and industrial support (Ferse et al., 2010; BoströmEinarsson et al., 2020) and lead to inaction (McAfee et al., 2019). Monitoring allows for the improvement of transplantation techniques and provides guidance for future restoration efforts (Collier et al., 2007). Most active restoration projects, including coral reefs, seagrasses, mangroves, saltmarshes, and oyster reefs, are generally short-term projects, limited to 1 or 2 years of duration (Bayraktarov et al., 2016). Of 362 case studies on shallow coral restoration, $60 \%$ reported less than 18 months of monitoring of restored sites (Boström-Einarsson et al., 2020). Contrarily, it should be noted that long-term monitoring (1520 years) has been considered as a paramount factor in properly evaluating the success of tropical, shallow coral restoration actions (Bayraktarov et al., 2016). Minimum time spans of 3040 years should be considered for a proper monitoring of restored CWC populations, due to their commonly slow growth rates and population dynamics (Bennecke et al., 2016). However, this is usually at odds with funding timeframes. Indeed, most active CWC restoration case studies performed to date lasted between 1 to 4 years (Figure 5). Longer actions (longer than 8 years) are associated with the initiation of the Louisiana Rigs-to-Reefs program in 1986 (Kaiser and Pulsipher, 2005; Kaiser et al., 2020).

Additionally, to achieve the more general recovery of ecosystem functioning, small-scale active restoration actions and tests already carried out with CWCs need to be properly scaled up (Elliott et al., 2007). In fact, there is a mismatch between the scale at which deep-sea ecological restoration can currently be performed and the scale at which major impacts act, as also highlighted for tropical shallow coral reefs (Edwards and Gomez, 2007; Montoya-Maya et al., 2016; Pollock et al., 2017). This is of particular concern for CWCs, because of the logistical challenges and limitations in performing and monitoring restoration actions over wide areas in the deep sea.

A combination of AUV and ROV inspection can allow for repeated monitoring of large restored areas over time (Armstrong et al., 2010; Morris et al., 2014; Benoist et al., 2019). The possibility for an AUV to autonomously acquire high-resolution images would allow scientists to generate a reference map for relocating 


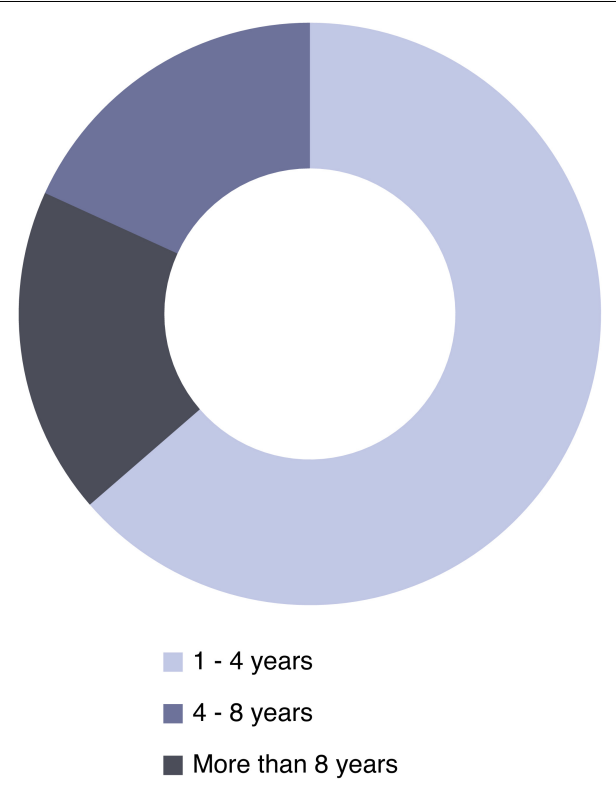

FIGURE 5 | Duration time of the CWC active restoration actions carried out to date $(N=12)$.

transplanted corals. These reference maps are imperative and should occur concurrently with restoration actions (Collier et al., 2007). Indeed, several studies have already efficiently applied photomosaic techniques for surveys of coral ecosystems (Pedersen et al., 2019), including CWC reefs (Boolukos et al., 2019). Recent advances in automated classification of CWCs from ROV images including live versus dead coral cover (Henry et al., 2016) combined with sonar imaging point to the possible future use of automatic classification of data acquired by AUVs to regularly monitor CWC populations, including restored ones (Williams et al., 2010; Huvenne et al., 2011; Henry et al., 2016; Sture et al., 2018).

Extensive monitoring performed with AUVs can be complemented with intensive survey performed with ROVs to acquire images of all, or a subsample of, the restored coral fragments, to monitor survival and growth through time. High-resolution images of the same individual coral fragment taken at different times, allows for the detection of small changes in the health of coral colonies as well as the measurement of in situ growth rates (Hsing et al., 2013; Girard and Fisher, 2018; Girard et al., 2019). For this purpose, the recent development in $3 \mathrm{D}$ photogrammetry for quantitative measurements and its application to ROV-acquired images of deep-sea fauna, including CWCs, is highly promising (Bennecke et al., 2016; Thornton et al., 2016; Prado et al., 2019). Additionally, staining techniques for assessing in situ growth rates of CWCs have been developed, offering another methodological basis to monitor transplant growth, although they require destructive sampling (Brooke and Young, 2009; Lartaud et al., 2013).

Finally, fixed-point deep-sea seafloor observatories with in situ cameras and instruments are now functioning in several areas of the world's oceans (Favali et al., 2010), allowing for continuous monitoring and observation of deep-sea fauna, including CWCs (Doya et al., 2014; Van Engeland et al., 2019) and also could be applied to the monitoring of restored CWC populations. Even so, their employment for monitoring CWC restoration actions is probably unnecessarily complex and expensive (for installation, maintenance and the analysis of the large amount of data they produce) compared to a wider periodic monitoring by combining AUVs and ROVs (Armstrong et al., 2008).

\section{Protecting the Restoration Effort}

Actively restored CWC ecosystems might continue to be exposed to further impacts from anthropogenic activities and ongoing global change (Ramirez-Llodra et al., 2011; Thresher et al., 2015). Consequently, appropriate selection of locations targeted for CWC active restoration actions should prioritize refugia areas forecasted to be sheltered from future impacts and extreme changes in environmental features driven by global change (Thresher et al., 2015; Sweetman et al., 2017; Morato et al., 2020). Active restoration may assist CWC habitat recovery once management is in place, but it will certainly fail without effective protection (Edwards et al., 2010). Conservation measures should precede active restoration to avoid any direct impacts that may compromise the restoration effort (Davies et al., 2007). However, effective management of deep-sea protected areas can be a challenge, particularly since most sites are located far offshore and in the High Seas (Davies et al., 2007). To this aim, global positioning surveillance of fishing vessels (Marrs and HallSpencer, 2002; Deng et al., 2005) and remote-imaging with large spatial coverage (Kourti et al., 2001, 2005) may become more cost effective for the monitoring of deep-sea MPAs (Davies et al., 2007).

\section{Costs for Actively Restoring CWC Ecosystems}

CWCs face many risks from the business activities of fisheries, oil and gas extraction, and mineral exploitation. These risks occur throughout the lifetime of an industrial project, from the initial exploration activities to the decommissioning and closure of operations. In order to deal with the continued impacts over the life of a project, economic sectors and industries are encouraged to adopt a "mitigation hierarchy" to first try to avoid, then to minimize, any significant adverse impacts, and finally, where these steps cannot eliminate environmental effects, to consider the potential for ecosystem restoration assuming the corresponding costs (Arlidge et al., 2018; Billett et al., 2019).

\section{Regulatory Mechanisms Aiding the Engagement of Industries in CWC Restoration}

In the case of fisheries, there has been good development of regulations to reduce impacts from bottom trawling. Deepwater fisheries are widespread and governed by regulations that depend on national jurisdiction, exclusive economic zones, regional sea authorities, and pan-international bodies (e.g., EU). The FAO has played a fundamental role in guiding states and Regional Fisheries Management Organizations (RFMOs) toward the conservation of species and habitats impacted by High Seas 
fishing operations (FAO, 2008, 2009a,b). In relation to CWCs, the most important outcomes have been the recommendations to identify, map, monitor and introduce measures to protect VMEs, to refrain from expanding fishing effort and its spatial extent, and reduce fishing effort in specific fisheries. Specific fisheries closures have been, and are being, put into effect under a number of schemes and authorities. "Move-on" rules are being adopted by various RFMOs requiring fishing vessels to stop fishing when a threshold of VME indicator is reached during fishing operations. VMEs are characterized by the presence of particular sensitive species, and the thresholds that constitute their "level of catch" and "minimum distance" are different in different RFMOs. In some cases, the designation of VMEs is contentious because they may continue to be targeted when present even if the weight of the catch falls slightly below the threshold level (Auster et al., 2011). Regulations have restricted access to sensitive areas and there may be recourses in the way of compensation and fines should vessels operate illegally in these areas. Liability or litigation payments have been made for accidental damage to sensitive coastal habitats from vessel grounding, but this is unlikely to occur for CWCs. However, there are additional and more direct ways that fishers can help in restoration. They have a good knowledge of the environments in which they are working and some degree of access to these sites through their fishing vessels. Coral bycatch from artisanal fishers is being used in collaborative projects as donor material for fragmentation in coral restoration experiments in the Atlantic (Azores), and Western Mediterranean (Cap de Creus) (Supplementary Boxes 1, 2). Society at large can also play a role in restoration by encouraging and pressing governments to develop and promote conservation policies and laws. For example, the general public in Ireland would be willing to pay a personal tax of $1 €$ annually to protect VME from trawling (Wattage et al., 2011). It is important to foster awareness about the importance of CWC ecosystems in order to increase society's interest and public support for their protection.

In the case of hydrocarbons and mineral industries, if the project cannot be moved to a different location in order to avoid impacts to CWCs, measures to minimize impacts may be introduced through engineering innovations and management actions. Industry operators then may explore potential options for ecosystem restoration once the impacts have ceased, such as rigs-to-reefs programs, as long as it makes ecological sense. Using subsea structures as potential artificial coral reef for natural colonization could offer considerable cost savings for the industry, government bodies and tax payers. From 2004 to 2018, in the framework of Louisiana Artificial Reef Program (Gulf of Mexico), industry paid an average \$392,000 per structure to the state for the decommissioning and subsequent use of obsolete structures as artificial reefs. In exchange, the state assumed the ownership and liability for the platforms (Kaiser et al., 2020). However, as mentioned above, there is a current debate about the implementation of rigs-toreefs programs.

Financing for fossil fuel and mineral extraction projects may also need to comply with the environmental and social safeguarding policies of International Finance Institutions (IFIs), such as the World Bank. Safeguards associated with loans and investments mean operators need to demonstrate how they will conform to the mitigation hierarchy, as indicators for how their projects will achieve good environmental performance (Hayes et al., 2015). At the project level, oil and gas operators should estimate the cost of each step of the hierarchy with respect to the biodiversity gains and losses incurred. In areas with CWCs that are costly to access and operate in, early costing and risk evaluation could result in the developers adopting options higher up the mitigation hierarchy. This might include avoiding sensitive sites, thereby reducing long-term costs by not having to restore them or offset damage (Arlidge et al., 2018). Notably, failure to adequately consider avoidance could cost operators more in the long run, not only through delays in operations caused by unintentional environmental impacts, but also relating to damage to their corporate reputation when accidents occur in sensitive environments (Hayes et al., 2015). These considerations are key parts of assessing and reducing risks to businesses.

In addition, subsea technologies involved in extractive industries (e.g., ROVs and AUVs) could also be used for environmental management tasks, making best use of standby time in operations (Cordes et al., 2016b). In future, regulations could also specifically require ecosystem restoration and build the resulting costs into Environmental Impact Statements at the time of submission, prior to the award of a contract for exploitation. The costs of CWC restoration and its subsequent monitoring following the end of extraction can be included in a Closure Plan.

\section{Restoration Costs}

Cost estimations for various hypothetical active restoration actions in the deep sea can be two to three orders of magnitude greater per hectare than costs for restoration in shallow-water ecosystems (Van Dover et al., 2014). The cost of shallowwater restoration initiatives, usually, ranged from US\$13,000 to US\$ > $1 \mathrm{M} \mathrm{ha}^{-1}$ (Spurgeon and Lindahl, 2000; Edwards et al., 2010). In contrast, in the scenario presented by Van Dover et al., (2014) for the active restoration of CWCs following bottom trawling impacts in the Darwin Mounds, the direct costs of only implementing a laboratory propagation-transplant protocol were estimated to be about US\$ $75 \mathrm{M} \mathrm{ha}^{-1}$. This estimate did not include the additional costs of geoengineering the seabed to reconstruct the mounds on which the corals were first found (Bett, 2001; Wheeler et al., 2004; Huvenne et al., 2016). When all of the costs are considered, including socio-economic, ecological and technological considerations, the conclusion was still that the overall balance would be moderately in favor of a (limited) active restoration with estimated cost in the order of US\$ 4.8 million (Van Dover et al., 2014).

However, not all active restoration actions in deep waters necessarily incur great costs. The restoration carried out in the Mediterranean continental using bycatch cold-water gorgonians (Supplementary Box 2) accounted for about \$US 170,000 ha ${ }^{-1}$; a significantly lower cost compared to what was estimated by Van Dover et al. (2014) and more in accordance with shallow-water restoration actions (Montseny et al., 2020). Thus, confirming the 
possibility of developing cost-effective techniques, even targeting deep-sea environments.

\section{LEARNING FROM SHALLOW-WATER CORAL RESTORATION TO ADVANCE CWC ACTIVE RESTORATION}

Overall, despite many challenges facing active CWC restoration, outcomes from the few assisted regeneration actions performed to date point to the feasibility of actively restoring CWC reefs and coral gardens under certain circumstances. As pointed out in this review, recent national and international research projects have started to address CWC restoration, and significant advances have been achieved. Ecological active restoration of CWCs is a field of study in an early stage of development, and the vast experience in shallow coral active restoration is a great opportunity to learn from their successes and failures to more successfully address the challenges of restoring CWC ecosystems.

Since the 1980s, different methodologies have been designed and widely implemented to actively restore tropical shallow coral reefs (Rinkevich, 1995, 2014; Young et al., 2012; Ng et al., 2015; Barton et al., 2017; Boström-Einarsson et al., 2020). In shallow waters, rearing of fragments of coral species in either ex situ or in situ nurseries and their subsequent transplantation to degraded areas has become the most common and successful approach for reef active restoration (Rinkevich, 2005; Edwards and Gomez, 2007; Edwards et al., 2010; Pizarro et al., 2014). For CWCs, slow growth rates, and the complex logistic and high costs for their maintenance in aquaria (Orejas et al., 2019), are the main constraints on ex situ rearing of fragments to be used in active restoration actions. Additionally, while some CWC species can be successfully maintained in aquaria, others cannot, showing high mortalities after only a few days or weeks (Orejas et al., 2019). Hence, additional research is needed to identify the best conditions for maintaining CWC species and foster their growth in aquaria. Specifically, we identify water flow, feeding frequency, and food quantity and composition as the main variables to be explored. The in situ rearing of CWC fragments entails difficulties and high costs for setting up appropriate structures in the deep sea by using underwater technologies (ROVs and manned submersibles), as well as for their monitoring through time. Additionally, difficulties in manipulation and cleaning of reared coral fragments do not allow for expected increase in survival or growth rates for in situ reared fragments.

Identification and selection of resilient coral phenotypes and/or genotypes to be used in active restoration actions of shallow coral reefs have recently been highlighted as a possible way to face the impacts driven by ongoing climate change (e.g., van Oppen et al., 2015; Morikawa and Palumbi, 2019). A similar approach is being explored for CWCs to identify resistant genotypes by means of experiments under controlled conditions (Kurman et al., 2017). We highlight the importance of additional investigation along these lines, particularly for the most frequent and abundant CWCs.
Promising results can be expected based on the high intraspecific variability commonly observed among coral fragments in their response to laboratory exposure to stress conditions (e.g., Hennige et al., 2015). Additionally, as for shallow coral reef restoration (Cabaitan et al., 2015; Ladd et al., 2018), we identify multi-specific restoration actions as a promising approach to foster positive interactions among species to speedup ecosystem recovery.

Substrate enhancement methods are also widespread in active shallow coral restoration techniques, either by creating or adding new substratum (such as artificial reefs) or by enhancing and stabilizing damaged substratum (Boström-Einarsson et al., 2020). For CWCs, high recruitment on artificial structures (Larcom et al., 2014) has highlighted this approach as being viable for the deep-sea. We identify research on the best composition, rugosity and morphology of the artificial structure for larval setting, survival and growth as paramount to advance with this approach for actively restoring CWC ecosystems. Moreover, additional knowledge is needed on reproductive and larval ecology and dispersion in the main CWC species, to identify the best locations and time for the deployment of the artificial structures.

Related to coral reproduction, larval enhancement methods, focused on increasing rates of coral fertilization, larval survival and recruitment, are also being applied in shallow coral reefs (Boström-Einarsson et al., 2020). However, these methods are difficult to apply to CWCs, for which knowledge on reproductive ecology is extremely scarce, and sexual reproduction and larvae obtention in aquaria has been successfully achived only for a very few species (Larsson et al., 2014; Strömberg and Larsson, 2017). Additional research on CWC maintenance can enhance the ability to successfully obtain larvae in aquaria, and we identify their settlement on artificial substrate and subsequent translocation to the field after metamorphosis as a possible way to increase larval survival and recruitment. However, growth rate and mortality after translocation need to be carefully monitored in the field to quantitatively assess the success of this method of larval enhancement for CWCs.

Recent reviews reported high survival rates of transplanted tropical shallow corals $(60-70 \%)$, highlighting that project failure was more related to a poor project design (inadequate site selection and ill-stated objectives) than to the technique used (Bayraktarov et al., 2016; Boström-Einarsson et al., 2020). It is crucial in any restoration project to establish realistic and clear objectives. In shallow-water environments, Boström-Einarsson et al. (2020) determined that a key missing objective of many restoration actions is the re-establishment of self-sustaining populations that would enhance natural larval production and recruitment processes. Furthermore, despite the well-known mismatch of the temporal and spatial scales of restoration projects and habitat degradation, shallow restoration actions are still mainly applied at small spatial extent and over limited time frames. For this reason, scientists are working on improving restoration techniques, with a special focus on scaling up both spatially and temporally (Bayraktarov et al., 2016; Tamburello et al., 2019; Boström-Einarsson et al., 2020). As for shallow-water corals, active restoration actions of CWC 
ecosystems need the establishment of clear and achievable objectives and the development of viable methods to scale-up the extent of restoration actions and as well as undertaking longer, standardized, and integrated monitoring programs. In this sense, we identify the improvement in underwater technologies and the ability of ROVs and AUVs to perform restoration actions and monitoring, as a key step forward for the ecological restoration of CWC ecosystems.

It is likely that the combination of well-designed passive and active restoration approaches will be the most effective, as currently employed in shallow-water marine ecosystems (Mitsch, 2014; Possingham et al., 2015). Wide-scale and long-term experiments combining a variety of methods and involving local actors should be tested to determine the ways in which simple interventions might enhance the rate of natural recolonization.

Ultimately, the benefits of involving local stakeholders (e.g., RFMOs, NGOs, statutory conservation bodies, oil and gas industry and future deep seabed mining, etc.) in the planning and implementation of restoration actions are well demonstrated in shallow coral restoration actions (Ferse, 2010; Bayraktarov et al., 2016; Hein et al., 2019; Boström-Einarsson et al., 2020), and are likely to be crucial for ensuring restoration success in CWC ecosystems, firstly, in order to ensure a suitable development of the restoration action, and then to preserve the restoration effort in the long term.

\section{AUTHOR CONTRIBUTIONS}

All authors listed have made a substantial, direct and intellectual contribution to the work, and approved it for publication.

\section{FUNDING}

MM was funded by a FPU 2014 research grant (FPU2014_06977) from the Spanish government (Spain). AGr received funding from a Juan de la Cierva 2015 research grant (IJCI-2015-23962) from the Spanish government. CL gratefully acknowledges the financial support by ICREA under the ICREA Academia

\section{REFERENCES}

Abelson, A. (2006). Artificial Reefs Vs Coral Transplantation as restoration tools for mitigating coral reef deterioration: benefits, concerns, and proposed guidelines. Bull. Mar. Sci. 78, 151-159.

Althaus, F., Williams, A., Alderslade, P., and Schlacher, T. A. (2017). Conservation of marine biodiversity on a very large deep continental margin: how representative is a very large offshore reserve network for deep-water octocorals? Divers. Distrib. 23, 90-103. doi: 10.1111/ddi.12501

Althaus, F., Williams, A., Schlacher, T. A., Kloser, R., Green, M. A., Barker, B. A., et al. (2009). Impacts of bottom trawling on deep-coral ecosystems of seamounts are long-lasting. Mar. Ecol. Prog. Ser. 397, 279-294. doi: 10.3354/ meps08248

Andrews, A. H., Cordes, E. E., Mahoney, M. M., Munk, K., Coale, K. H., Cailliet, G. M., et al. (2002). Age, growth and radiometric age validation of a deep-sea, habitat-forming gorgonian (Primnoa resedaeformis) from the Gulf of Alaska. Hydrobiologia 471, 101-110. doi: 10.1023/A:1016501320206

Arlidge, W. N. S., Bull, J. W., Addison, P. F. E., Burgass, M. J., Gianuca, D., Gorham, T. M., et al. (2018). A global mitigation hierarchy for nature conservation. Bioscience 68, 336-347. doi: 10.1093/biosci/biy029 program. This study was supported by the SHELFRECOVER project funded by the Fundación BBVA and the European Union's Horizon 2020 Research and Innovation Program under grant agreements nos. 689518 (MERCES) and 678760 (ATLAS).

\section{ACKNOWLEDGMENTS}

The present review is based on the discussions derived from First International Meeting on the Ecological Restoration of DeepSea Coral Populations, held in Barcelona on 21-23 November 2016. The meeting was conducted within the frame of the SHELFRECOVER project founded by the Fundación BBVA. The review was also possible thanks to the temporary stay that MM carried out from May to August 2018 in the Instituto do Mar, Departamento de Oceanografia e Pescas da Universidade dos Açores -IMAR (Azores, Portugal). Some of the authors are part of the Marine Conservation research group (www.medrecover.org) (2017 SGR 1521) from the Generalitat de Catalunya. We also thank the Fundación Biodiversidad of the Spanish Ministry for the Ecological transition through the Pleamar Programme (RESCAP project), co-funded by the European Maritime and Fisheries Fund.

\section{SUPPLEMENTARY MATERIAL}

The Supplementary Material for this article can be found online at: https://www.frontiersin.org/articles/10.3389/fmars. 2021.621151/full\#supplementary-material

Supplementary Box 1 | Bycatch gorgonians transplanted onto artificial structures.

Supplementary Box 2|A cost-effective and large-scale method to transplant gorgonians.

Supplementary Box $\mathbf{3} \mid$ ROV-based translocation of coral fragments.

Supplementary Box 4 | Restoration of Lophelia pertusa reef habitats in Skagerrak: enhancement of larval settling.

Supplementary Box 5 | Coral colonization of oil and gas platforms.

Armstrong, C. W., Foley, N. S., Kahui, V., and Grehan, A. (2014). Cold water coral reef management from an ecosystem service perspective. Mar. Policy 50, 126-134. doi: 10.1016/j.marpol.2014.05.016

Armstrong, R. A., Singh, H., and Kunz, C. (2010). Large-scale mapping and characterization of deep reef habitats in the US Caribbean. Proc. Gulf Caribbean Fish. Inst. 63, 134-138.

Armstrong, R., Singh, H., Rivero, S., and Gilbes, F. (2008). Monitoring coral reefs in optically-deep waters. Proceedings of the 11th International Coral Reef Symposium. Florida: 7-11.

Aronson, J., Blignaut, J. N., and Aronson, T. B. (2017). Conceptual frameworks and references for landscape-scale restoration: reflecting back and looking forward. Ann. Missouri Bot. Gard. 102, 188-200. doi: 10.3417/2017003

Auster, P. J., Gjerde, K., Heupel, E., Watling, L., Grehan, A., and Rogers, A. D. (2011). Definition and detection of vulnerable marine ecosystems on the high seas: Problems with the "move-on" rule. ICES J. Mar. Sci. 68, 254-264. doi: 10.1093/icesjms/fsq074

Babcock, M. M., Harris, P. M., Carls, M. G., Brodersen, C. C., and Rice, S. D. (1998). Mussel bed restoration and monitoring. Exxon Valdez oil spill restoration project 95090: Final report. Alaska: Exon Valdez Oil Spill Restoration Project Final Report. 
Baco, A. R., Morgan, N., Roark, E. B., Silva, M., Shamberger, K. E. F., and Miller, K. (2017). Defying dissolution: discovery of deep-sea scleractinian coral reefs in the North Pacific. Sci. Rep. 7, 1-11. doi: 10.1038/s41598-017-05492-w

Baco, A. R., Roark, E. B., and Morgan, N. B. (2019). Amid fields of rubble, scars, and lost gear, signs of recovery observed on seamounts on 30- to 40-year time scales. Sci. Adv. 5, 1-8. doi: 10.1126/sciadv.aaw4513

Baggett, L. P., Powers, S. P., Brumbaugh, R. D., Coen, L. D., Deangelis, B. M., Greene, J. K., et al. (2015). Guidelines for evaluating performance of oyster habitat restoration. Restor. Ecol. 23, 737-745. doi: 10.1111/rec.12262

Baillon, S., Hamel, J. F., Wareham, V. E., and Mercier, A. (2012). Deep coldwater corals as nurseries for fish larvae. Front. Ecol. Environ. 10, 351-356. doi: $10.1890 / 120022$

Bakker, J. P., Esselink, P., Dijkema, K. S., Van Duin, W. E., and De Jong, D. J. (2002). Restoration of salt marshes in the Netherlands. Hydrobiologia 478, 29-51. doi: 10.1023/A:1021066311728

Barton, J. A., Willis, B. L., and Hutson, K. S. (2017). Coral propagation: a review of techniques for ornamental trade and reef restoration. Rev. Aquac. 9, 238-256. doi: $10.1111 / \mathrm{raq} .12135$

Basconi, L., Cadier, C., and Guerrero-Limón, G. (2020). "Challenges in marine restoration ecology: how techniques, assessment metrics, and ecosystem valuation can lead to improved restoration success," in YOUMARES 9 - The Oceans: Our Research, Our Future, eds S. Jungblut, V. Liebich, and M. BodeDalby (Cham: Springer), 83-99.

Baussant, T., Nilsen, M., Ravagnan, E., Westerlund, S., and Ramanand, S. (2018). Effects of suspended drill cuttings on the coral Lophelia pertusa using pulsed and continuous exposure scenarios. J. Toxicol. Environ. Heal. Part A Curr. Issues 81, 361-382. doi: 10.1080/15287394.2018.1444375

Bayraktarov, E., Saunders, M. I., Abdullah, S., Mills, M., Beher, J., Possingham, H. P., et al. (2016). The cost and feasibility of marine coastal restoration. Ecol. Appl. 26, 1055-1074. doi: 10.1890/15-1077.1

Bekkby, T., Papadopoulou, N., Fiorentino, D., McOwen, C. J., Rinde, E., Boström, C., et al. (2020). Habitat features and their influence on the restoration potential of marine habitats in Europe. Front. Mar. Sci. 7, 1-12. doi: 10.3389/fmars.2020. 00184

Bennecke, S., and Metaxas, A. (2017). Effectiveness of a deep-water coral conservation area: evaluation of its boundaries and changes in octocoral communities over 13 years. Deep. Res. Part II Top. Stud. Oceanogr. 137, 420-435. doi: 10.1016/j.dsr2.2016.06.005

Bennecke, S., Kwasnitschka, T., Metaxas, A., and Dullo, W. C. (2016). In situ growth rates of deep-water octocorals determined from $3 \mathrm{D}$ photogrammetric reconstructions. Coral Reefs 35, 1227-1239. doi: 10.1007/s00338-016-1471-7

Benoist, N. M. A., Morris, K. J., Bett, B. J., Durden, J. M., Huvenne, V. A. I., Le Bas, T. P., et al. (2019). Monitoring mosaic biotopes in a marine conservation zone by autonomous underwater vehicle. Conserv. Biol. 33, 1174-1186. doi: 10.1111/cobi.13312

Bergmark, P., and Jorgensen, D. (2014). Lophelia pertusa conservation in the North Sea using obsolete offshore structures as artificial reefs. Mar. Ecol. Prog. Ser. 516, 275-280. doi: 10.3354/meps10997

Bett, B. J. (2001). UK Atlantic margin environmental survey: introduction and overview of bathyal benthic ecology. Continental Shelf Res. 21, 917-956. doi: 10.1016/S0278-4343(00)00119-9

Billett, D. S. M., Jones, D. O. B., and Weaver, P. P. (2019). "Improving environmental management practices in deep-sea mining," in "Environmental issues of deep-sea mining: Impacts, Consequences and Policy Perspectives, ed. R. Sharma (Switzerland: Springer), 403-446.

Bo, M., Bava, S., Canese, S., Angiolillo, M., Cattaneo-Vietti, R., and Bavestrello, G. (2014). Fishing impact on deep Mediterranean rocky habitats as revealed by ROV investigation. Biol. Conserv. 171, 167-176. doi: 10.1016/j.biocon.2014.01. 011

Boavida, J., Paulo, D., Aurelle, D., Arnaud-Haond, S., Marschal, C., Reed, J., et al. (2016). A well-kept treasure at depth: Precious red coral rediscovered in atlantic deep coral gardens (SW Portugal) after 300 Years. PLoS One 11:e0147228. doi: 10.1371/journal.pone.0147228

Boch, C. A., Devogelaere, A., Burton, E. J., King, C., Lovera, K., Buck, J., et al. (2020). Guide to translocating coral Fragments for deep-sea restoration. Marine Sanctuaries Conservation Series ONMS-20-10. Available Online at: https://sanctuaries.noaa.gov/science/conservation/translocating-coralfragments-for-deep-sea-restoration.html.
Boch, C. A., Devogelaere, A., Burton, E., King, C., Lord, J., Lovera, C., et al. (2019). Coral Translocation as a method to restore impacted deepsea coral communities. Front. Mar. Sci. 6:540. doi: 10.3389/fmars.2019. 00540

Bongiorni, L., Shafir, S., Angel, D., and Rinkevich, B. (2003). Survival, growth and gonad development of two hermatypic corals subjected to in situ fishfarm nutrient enrichment. Mar. Ecol. Prog. Ser. 253, 137-144. doi: 10.3354/ meps 253137

Boolukos, C. M., Lim, A., O’Riordan, R. M., and Wheeler, A. J. (2019). Cold-water corals in decline - A temporal (4 year) species abundance and biodiversity appraisal of complete photomosaiced cold-water coral reef on the Irish Margin. Deep. Res. Part I Oceanogr. Res. Pap. 146, 44-54. doi: 10.1016/j.dsr.2019.03.004

Bosire, J. O., Dahdouh-Guebas, F., Walton, M., Crona, B. I., Lewis, R. R., Field, C., et al. (2008). Functionality of restored mangroves: A review. Aquat. Bot. 89, 251-259. doi: 10.1016/j.aquabot.2008.03.010

Boström-Einarsson, L., Babcock, R. C., Bayraktarov, E., Ceccarelli, D., Cook, N., Ferse, S. C. A., et al. (2020). Coral restoration - A systematic review of current methods, successes, failures and future directions. PLoS One 15:e0226631. doi: 10.1371/journal.pone.0226631

Brooke, S., and Young, C. M. (2003). Reproductive ecology of a deepwater scleractinian coral, Oculina varicosa, from the southeast Florida shelf. Cont. Shelf Res. 23, 847-858. doi: 10.1016/S0278-4343(03)0 0080-3

Brooke, S., and Young, C. M. (2009). In situ measurement of survival and growth of Lophelia pertusa in the northern Gulf of Mexico. Mar. Ecol. Prog. Ser. 397, 153-161. doi: 10.3354/meps08344

Brooke, S., Koenig, C. C., and Shepard, A. N. (2006). Oculina Banks restoration project: description and preliminary assessment. Proceedings of the 57th Gulf and Caribbean Fisheries Institute. 607-620.

Brumbaugh, R. D., Beck, M. W., Coen, L. D., Craig, L., and Hick, P. (2006). A practitioners guide to the Design \& Monitoring of Shellfish Restoration Projects: an ecosystem approach. Arlington, VA: The Nature Conservancy, 1-32.

Bruno, J. F., Stachowicz, J. J., and Bertness, M. D. (2003). Inclusion of facilitation into ecological theory. Trends Ecol. Evol. 18, 119-125. doi: 10.1016/S01695347(02)00045-9

Bruno, J., and Bertness, D. (2001). Positive interactions, facilitations and foundation species. Sunderland, MA: Inc Publishers.

Buddemeier, R. W., and Kinzie, R. A. III (1976). Coral growth. Oceanogr. Mar. Biol. Annu. Rev. 14, 183-225.

Buhl-Mortensen, L., and Buhl-Mortensen, P. (2004). Symbiosis in deep-water corals. Symbiosis 37, 33-61.

Buhl-Mortensen, L., Vanreusel, A., Gooday, A. J., Levin, L. A., Priede, I. G., Buhl-Mortensen, P., et al. (2010). Biological structures as a source of habitat heterogeneity and biodiversity on the deep ocean margins. Mar. Ecol. 31, 21-50. doi: 10.1111/j.1439-0485.2010.00359.x

Buhl-Mortensen, P., and Buhl-Mortensen, L. (2005). Morphology and growth of the deep-water gorgonians Primnoa resedaeformis and Paragorgia arborea. Mar. Biol. 147, 775-788. doi: 10.1007/s00227-005-1604-y

Buhl-Mortensen, P., and Buhl-Mortensen, L. (2018). Impacts of bottom trawling and litter on the seabed in Norwegian waters. Front. Mar. Sci. 4:42. doi: 10.3389/ fmars.2018.00042

Buhl-Mortensen, P., Buhl-Mortensen, L., Gordon, J., Fader, G. B. J., Mckeown, D. L., and Fenton, D. G. (2005). Effects on fisheries on deepwater gorgonian corals in the Northeast Channel, Nova Scotia. Am. Fish. Soc. Symp. 41, 369-382.

Burdett, H. L., Carruthers, M., Donohue, P. J. C., Wicks, L. C., Hennige, S. J., Roberts, J. M., et al. (2014). Effects of high temperature and CO2 on intracellular DMSP in the cold-water coral Lophelia pertusa. Mar. Biol. 161, 1499-1506. doi: 10.1007/s00227-014-2435-5

Burgess, S. N., and Babcock, R. C. (2005). "Reproductive ecology of three reefforming, deep-sea corals in the New Zealand region," in Cold-Water Corals and Ecosystems, eds A. Freiwald and J. M. Roberts (Berlin, Heidelberg: Springer), 701-713.

Cabaitan, P. C., Yap, H. T., and Gomez, E. D. (2015). Performance of single versus mixed coral species for transplatation to restore degraded reefs. Restor. Ecol. 23, 349-356. doi: 10.1111/rec.12205

Cardinale, B. J., Duffy, J. E., Gonzalez, A., Hooper, D. U., Perrings, C., Venail, P., et al. (2012). Biodiversity loss and its impact on humanity. Nature 486, 59-67. doi: $10.1038 /$ nature 11148 
Cathalot, C., Van Oevelen, D., Cox, T. J. S., Kutti, T., Lavaleye, M., Duineveld, G., et al. (2015). Cold-water coral reefs and adjacent sponge grounds: hotspots of benthic respiration and organic carbon cycling in the deep sea. Front. Mar. Sci. 2:37. doi: 10.3389/fmars.2015.00037

Christiansen, B., Denda, A., and Christiansen, S. (2019). Potential effects of deep seabed mining on pelagic and benthopelagic biota. Mar. Policy 114:103442. doi: 10.1016/j.marpol.2019.02.014

Clark, M. R., Althaus, F., Schlacher, T. A., Williams, A., Bowden, D. A., and Rowden, A. A. (2016). The impacts of deep-sea fisheries on benthic communities: A review. ICES J. Mar. Sci. 73, i51-i69. doi: 10.1093/icesjms/ fsv123

Clark, M. R., Bowden, D. A., Rowden, A. A., and Stewart, R. (2019). Little evidence of benthic community resilience to bottom trawling on seamounts after 15 years. Front. Mar. Sci. 6:63. doi: 10.3389/fmars.2019.00063

Clark, S., and Edwards, A. J. (1995). Coral transplantation as an aid to reef rehabilitation: evaluation of a case study in the Maldive Islands. Coral Reefs 14, 201-213. doi: 10.1007/BF00334342

Collier, C., Dodge, R. E., Gilliam, D., Gracie, K., Gregg, L., Jaap, W., et al. (2007). Rapid response and restoration for coral reef injuries in southeast Florida: Guidelines and recommendations. Florida: Nova Southeastern University, 1-57.

Corbera, G., Lo Iacono, C., Gràcia, E., Grinyó, J., Pierdomenico, M., Huvenne, V. A. I., et al. (2019). Ecological characterisation of a Mediterranean coldwater coral reef: Cabliers Coral Mound Province (Alboran Sea, western Mediterranean). Prog. Oceanogr. 175, 245-262. doi: 10.1016/j.pocean.2019.04. 010

Cordes, E. E., Arnaud-Haond, S., Bergstad, O. A., da Costa Falcao, A. P., Freiwald, A., and Roberts, J. M. (2016a). "Chapter 42: Cold-Water Corals," in The First Global Integrated Marine Assessment: World Ocean Assessment, eds L. Inniss, A. Simcock, and United Nations General Assembly (Cambridge: Cambridge University Press), 973.

Cordes, E. E., Jones, D. O. B., Schlacher, T. A., Amon, D. J., Bernardino, A. F., Brooke, S., et al. (2016b). Environmental impacts of the deep-water oil and gas industry: A review to guide management strategies. Front. Environ. Sci. 4:58. doi: $10.3389 /$ fenvs.2016.00058

Cordes, E. E., McGinley, M. P., Podowski, E. L., Becker, E. L., Lessard-Pilon, S., Viada, S. T., et al. (2008). Coral communities of the deep Gulf of Mexico. Deep. Res. Part I Oceanogr. Res. Pap. 55, 777-787. doi: 10.1016/j.dsr.2008.03.005

Cordes, E. E., Nybakken, J. W., and VanDykhuizen, G. (2001). Reproduction and growth of Anthomastus ritteri (Octocorallia: Alcyonacea) from Monterey Bay, California, USA. Mar. Biol. 138, 491-501. doi: 10.1007/s0022700 00470

Costello, M. J., McCrea, M., Freiwald, A., Lundälv, T., Jonsson, L., Bett, B. J., et al. (2005). "Role of cold-water Lophelia pertusa coral reefs as fish habitat in the NE Atlantic," in Cold-Water Corals and Ecosystems, eds A. Freiwald and J. M. Roberts (Berlin: Springer), 771-805.

Cudney-Bueno, R., Lavín, M. F., Marinone, S. G., Raimondi, P. T., and Shaw, W. W. (2009). Rapid effects of marine reserves via larval dispersal. PLoS One 4:e04140. doi: 10.1371/journal.pone.0004140

D’Onghia, G., Maiorano, P., Sion, L., Giove, A., Capezzuto, F., Carlucci, R., et al. (2010). Effects of deep-water coral banks on the abundance and size structure of the megafauna in the Mediterranean Sea. Deep. Res. Part II Top. Stud. Oceanogr. 57, 397-411. doi: 10.1016/j.dsr2.2009.08.022

Da Ros, Z., Dell'Anno, A., Morato, T., Sweetman, A. K., Carreiro-Silva, M., Smith, C. J., et al. (2019). The deep sea: The new frontier for ecological restoration. Mar. Policy 108:103642. doi: 10.1016/j.marpol.2019.103642

Dahl, M. P., Pereyra, R. T., Lundälv, T., and André, C. (2012). Fine-scale spatial genetic structure and clonal distribution of the cold-water coral Lophelia pertusa. Coral Reefs 31, 1135-1148. doi: 10.1007/s00338-012-0937-5

Dannheim, J., Beermann, J., Lacroix, G., De Mesel, I., Kerckhof, F., Schön, I., et al. (2018). Understanding the influence of man-made structures on the ecosystem functions of the North Sea (UNDINE). Netherlands: Wageningen Marine Research.

Danovaro, R., Corinaldesi, C., Dell'Anno, A., and Snelgrove, P. V. R. (2017). The deep-sea under global change. Curr. Biol. 27, R461-R465. doi: 10.1016/j.cub. 2017.02.046

Davies, A. J., Roberts, J. M., and Hall-Spencer, J. (2007). Preserving deep-sea natural heritage: Emerging issues in offshore conservation and management. Biol. Conserv. 138, 299-312. doi: 10.1016/j.biocon.2007.05.011
Dayton, P. K. (2003). The importance of the natural sciences to conservation: (An American Society of Naturalists Symposium Paper). Am. Nat. 162, 1-13.

De Moura Neves, B. (2016). Growth in cold-water octocorals: rates, morphology and environmental controls. Dr. thesis. Canada: Memorial University of Newfoundland.

De'ath, G., Lough, J. M., and Fabricius, K. E. (2009). Declining coral calcification on the Great Barrier Reef. Science 323, 116-119. doi: 10.1126/science.1165283

DeLeo, D. M., Ruiz-Ramos, D. V., Baums, I. B., and Cordes, E. E. (2016). Response of deep-water corals to oil and chemical dispersant exposure. Deep. Res. Part II Top. Stud. Oceanogr. 129, 137-147. doi: 10.1016/j.dsr2.2015.02.028

Demopoulos, A. W., Bourque, J. R., and Frometa, J. (2014). Biodiversity and community composition of sediment macrofauna associated with deep-sea Lophelia pertusa habitats in the Gulf of Mexico. Deep Sea Research Part I: Oceanogr. Res. Pap. 93, 91-103. doi: 10.1016/j.dsr.2014.07.014

Deng, R., Dichmont, C., Milton, D., Haywood, M., Vance, D., Hall, N., et al. (2005). Can vessel monitoring system data also be used to study trawling intensity and population depletion? The example of Australia's northern prawn fishery. Can. J. Fish. Aquat. Sci. 62, 611-622. doi: 10.1139/f04-219

DeVogelaere, A. P., Burton, E. J., Trejo, T., King, C. E., Clague, D. A., Tamburri, M. N., et al. (2005). "Deep-sea corals and resource protection at the Davidson Seamount, California, U.S.A," in Cold-water Corals and Ecosystems, eds A. Freiwald and J. M. Roberts (Berlin, Heidelberg: Springer-Verlag), 1189-1198.

Dodds, L. A., Black, K. D., Orr, H., and Roberts, J. M. (2009). Lipid biomarkers reveal geographical differences in food supply to the cold-water coral Lophelia pertusa (Scleractinia). Mar. Ecol. Prog. Ser. 397, 113-124. doi: 10.3354/ meps08143

Doya, C., Aguzzi, J., Pardo, M., Matabos, M., Company, J. B., Costa, C., et al. (2014). Diel behavioral rhythms in sablefish (Anoplopoma fimbria) and other benthic species, as recorded by the Deep-sea cabled observatories in Barkley canyon (NEPTUNE-Canada). J. Mar. Syst. 130, 69-78. doi: 10.1016/j.jmarsys.2013.04. 003

Duarte, C. M., Agusti, S., Barbier, E., Britten, G. L., Castilla, J. C., Gattuso, J.-P., et al. (2020). Rebuilding marine life. Nature 580, 39-51. doi: 10.1038/s41586020-2146-7

Durán Muñoz, P., Murillo, F. J., Sayago-Gil, M., Serrano, A., Laporta, M., Otero, I., et al. (2011). Effects of deep-sea bottom longlining on the Hatton Bank fish communities and benthic ecosystem, north-east Atlantic. J. Mar. Biol. Assoc. $U$ K. 91, 939-952. doi: 10.1017/S0025315410001773

Durán Muñoz, P., Sayago-Gil, M., Cristobo, J., Parra, S., Serrano, A., Díaz Del, et al. (2009). Seabed mapping for selecting cold-water coral protection areas on Hatton Bank, Northeast Atlantic. ICES J. Mar. Sci. 66, 2013-2025. doi: 10.1093/icesjms/fsp170

Edwards, A. J., and Gomez, E. D. (2007). Reef restoration. Concepts and guidelines: making sensible management choices in the face of uncertainity. Available Online at: http://www.gefcoral.org/Portals/25/workgroups/rr_guidelines/rrg_ fullguide.pdf

Edwards, A. J., Guest, J., Shafir, S., Fisk, D., Gomez, E., Rinkevich, B., et al. (2010). Reef Rehabilitation manual. St Lucia, Australia: Coral Reef Targeted Research \& Capacity Building for Management Program.

Elliott, M., Burdon, D., Hemingway, K. L., and Apitz, S. E. (2007). Estuarine, coastal and marine ecosystem restoration: Confusing management and science - A revision of concepts. Estuar. Coast. Shelf Sci. 74, 349-366. doi: 10.1016/j.ecss. 2007.05.034

Falk, D. A., Palmer, M. A., and Zedler, J. B. (2006). Foundations of Restoration Ecology. Washington, DC: Island Press.

FAO. (2008). Report of the expert consultation on international guidelines for the management of deep-sea fisheries in the High Seas. Rome: FAO.

FAO. (2009a). International guidelines for the management of deep-sea fisheries in the high seas. Rome: FAO.

FAO. (2009b). Report of the technical consultation on international guidelines for the management of deep-sea Fisheries in the High Seas. Rome. 4-8 February and 25-29 August 2008. Rome: FAO.

Fava, F., Bavestrello, G., Valisano, L., and Cerrano, C. (2010). Survival, growth and regeneration in explants of four temperate gorgonian species in the Mediterranean Sea. Ital. J. Zool. 77, 44-52. doi: 10.1080/11250000902769680

Favali, P., Person, R., Barnes, C. R., Kaneda, Y., Delaney, J. R., and Hsu, S. (2010). Seafloor observatory science. Proc. Ocean. 9, 21-25. 
Ferse, S. C. A. (2010). Poor performance of corals transplanted onto substrates of short durability. Restor. Ecol. 18, 399-407. doi: 10.1111/j.1526-100X.2010. 00682.x

Ferse, S. C. A., Máñez Costa, M., Mez, K. S., Adhuri, D. S., and Glaser, M. (2010). Allies, not aliens: Increasing the role of local communities in marine protected area implementation. Environ. Conserv. 37, 23-34. doi: 10.1017/ S0376892910000172

Fisher, C. R., Hsing, P. Y., Kaiser, C. L., Yoerger, D. R., Roberts, H. H., Shedd, W. W., et al. (2014). Footprint of deepwater horizon blowout impact to deepwater coral communities. Proc. Natl. Acad. Sci. U. S. A. 111, 11744-11749. doi: 10.1073/pnas.1403492111

Fock, A., and Millar, I. (2008). Oxygen toxicity in recreational and technical diving. Diving Hyperb. Med. 38, 86-90.

Fonesca, M. S., Kenworthy, W. J., Julius, B. E., Shutler, S., and Fluke, S. (2002). "Seagrasses," in Handbook of Ecological Restoration. Restorat. Prac. 2, 149-170. doi: $10.2134 /$ jeq2004.2389

Forrester, G. E., O’Connell-Rodwell, C., Baily, P., Forrester, L. M., Giovannini, S., Harmon, L., et al. (2011). Evaluating methods for transplanting endangered elkhorn corals in the Virgin Islands. Restor. Ecol. 19, 299-306. doi: 10.1111/j. 1526-100X.2010.00664.x

Fowler, A. M., Jørgensen, A. M., Svendsen, J. C., Macreadie, P. I., Jones, D. O. B., Boon, A. R., et al. (2018). Environmental benefits of leaving offshore infrastructure in the ocean. Front. Ecol. Environ. 16, 571-578. doi: 10.1002/fee. 1827

Fox, A. D., Henry, L. A., Corne, D. W., and Roberts, J. M. (2016). Sensitivity of marine protected area network connectivity to atmospheric variability. $R$. Soc. Open Sci. 3:160494. doi: 10.1098/rsos.160494

Freiwald, A., and Roberts, J. M. (2005). Cold-water corals and ecosystems. Berlin Heidelberg: Springer-Verlag.

Freiwald, A., Fossa, J. H., Grehan, A., Koslow, J. A., and Roberts, J. M. (2004). Coldwater coral reef. Out of sight - no longer out of mind. Cambridge: UNEP-WCMC.

Galloway, K. C., Becker, K. P., Phillips, B., Kirby, J., Licht, S., Tchernov, D., et al. (2016). Soft robotic grippers for biological sampling on deep reefs. Soft Robot. 3, 23-33. doi: 10.1089/soro.2015.0019

Gann, G. D., McDonald, T., Aronson, J., Dixon, K. W., Walder, B., Hallett, J. G., et al. (2018). The SER Standards: a globally relevant and inclusive tool for improving restoration practice - a reply to Higgs et al. Restor. Ecol. 26, 426-430. doi: $10.1111 /$ rec. 12819

Gann, G. D., McDonald, T., Walder, B., Aronson, J., Nelson, C. R., Jonson, J., et al. (2019). International principles and standards for the practice of ecological restoration. Second edition. Restor. Ecol. 27, S1-S46. doi: 10.1111/rec.13035

Geist, J., and Hawkins, S. J. (2016). Habitat recovery and restoration in aquatic ecosystems: current progress and future challenges. Aquat. Conserv. Mar. Freshw. Ecosyst. 26, 942-962. doi: 10.1002/aqc.2702

George, R. Y., Okey, T. A., Reed, J. K., and Stone, R. P. (2007). Ecosystem-based fisheries management of seamount and deep-sea coral reefs in U.S. waters: conceptual models for proactive decisions. Bull. Mar. Sci. Miami 81, 9-30.

Georgian, S. E., Dupont, S., Kurman, M., Butler, A., Strömberg, S. M., Larsson, A. I., et al. (2016). Biogeographic variability in the physiological response of the coldwater coral Lophelia pertusa to ocean acidification. Mar. Ecol. 37, 1345-1359. doi: $10.1111 /$ maec. 12373

Girard, F., and Fisher, C. R. (2018). Long-term impact of the Deepwater Horizon oil spill on deep-sea corals detected after seven years of monitoring. Biol. Conserv. 225, 117-127. doi: 10.1016/j.biocon.2018.06.028

Girard, F., Cruz, R., Glickman, O., Harpster, T., and Fisher, C. R. (2019). In situ growth of deep-sea octocorals after the Deepwater Horizon oil spill. Elem. Sci. Anth. 7:12. doi: 10.1525/elementa.349

Girard, F., Lacharité, M., and Metaxas, A. (2016). Colonization of benthic invertebrates in a submarine canyon in the NW Atlantic. Mar. Ecol. Prog. Ser. 544, 53-64. doi: 10.3354/meps 11555

Girard, F., Shea, K., and Fisher, C. R. (2018). Projecting recovery of a longlived deep-sea coral species after the Deepwater Horizon oil spill using statestructured models. J. Appl. Ecol. 55, 1812-1822. doi: 10.1111/1365-2664.13141

Gollner, S., Kaiser, S., Menzel, L., Jones, D. O. B., Brown, A., Mestre, N. C., et al. (2017). Resilience of benthic deep-sea fauna to mining activities. Mar. Environ. Res. 129, 76-101. doi: 10.1016/j.marenvres.2017.04.010

Gómez, C. E., Wickes, L., Deegan, D., Etnoyer, P. J., and Cordes, E. E. (2018). Growth and feeding of deep-sea coral Lophelia pertusa from the California margin under simulated ocean acidification conditions. PeerJ 6:e5671. doi: 10 $7717 /$ peerj.5671

Gori, A., Ferrier-Pagès, C., Hennige, S. J., Murray, F., Rottier, C., Wicks, L. C., et al. (2016). Physiological response of the cold-water coral Desmophyllum dianthus to thermal stress and ocean acidification. PeerJ 2016, 1-16. doi: 10.7717/peerj. 1606

Gross, M. (2015). Deep sea in deep trouble? Curr. Biol. 25, R1019-R1021. doi: 10.1016/j.cub.2015.10.030

Guinotte, J. M., Orr, J., Cairns, S., Freiwald, A., Morgan, L., and George, R. (2006). Will human-induced changes in seawater chemistry alter the distribution of deep-sea scleractinian corals? Front. Ecol. Environ. 4, 141-146.

Hall-Spencer, J., Allain, V., and Fossa, J. H. (2002). Trawling damage to Northeast Atlantic ancient coral reefs. Proc. R. Soc. B Biol. Sci. 269, 507-511. doi: 10.1098/ rspb.2001.1910

Halpern, B. S., Silliman, B. R., Olden, J. D., Bruno, J. P., and Bertness, M. D. (2007). Incorporating positive interactions in aquatic restoration and conservation. Front. Ecol. Environ. 5, 153-160.

Harter, S. L., Ribera, M. M., Shepard, A. N., and Reed, J. K. (2009). Assessment of fish populations and habitat on Oculina bank, a deep-sea coral marine protected area off eastern Florida. Fish. Bull. 107, 195-206.

Hayes, G., Whitaker, S., Brooks, S., Marsh, D., Kowalska, A., Costelloe, B., et al. (2015). Strengthening Implementation of the Mitigation Hierarchy: Managing Biodiversity Risk for Conservation Gains. A Cambridge Conservation Initiative - Collaborative Fund Project Report Compiled By: BirdLife International. UNEPWCMC, RSPB, FFI, and the University of Cambridge. Cambridge: University of Cambridge.

Hein, M. Y., Birtles, A., Willis, B. L., Gardiner, N., Beeden, R., and Marshall, N. A. (2019). Coral restoration: Socio-ecological perspectives of benefits and limitations. Biol. Conserv. 229, 14-25. doi: 10.1016/j.biocon.2018.11.014

Hennige, S. J., Wicks, L. C., Kamenos, N. A., Perna, G., Findlay, H. S., and Roberts, J. M. (2015). Hidden impacts of ocean acidification to live and dead coral framework. Proc. R. Soc. B Biol. Sci. 282:990. doi: 10.1098/rspb.2015.0990

Henry, L. A., and Roberts, J. M. (2007). Biodiversity and ecological composition of macrobenthos on cold-water coral mounds and adjacent off-mound habitat in the bathyal Porcupine Seabight, NE Atlantic. Deep. Res. Part I Oceanogr. Res. Pap. 54, 654-672. doi: 10.1016/j.dsr.2007.01.005

Henry, L. A., Mayorga-Adame, C. G., Fox, A. D., Polton, J. A., Ferris, J. S., McLellan, F., et al. (2018). Ocean sprawl facilitates dispersal and connectivity of protected species. Sci. Rep. 8, 1-11. doi: 10.1038/s41598-018-29575-4

Henry, L. A., Mukherjee, S. S., Robertson, N. M., De Clippele, L., and Roberts, J. M. (2016). Deep corals, deep learning: moving the deep net towards realtime image annotation. Boston: International Symposium on Deep-Sea Corals, 12-16.

Higgs, E., Falk, D. A., Guerrini, A., Hall, M., Harris, J., Hobbs, R. J., et al. (2014). The changing role of history in restoration ecology. Front. Ecol. Environ. 12, 499-506. doi: 10.1890/110267

Hilbertz, W. H., and Goreau, T. J. (1996). U.S. Patent No. 5,543,034. Washington, DC: U.S. Patent and Trademark Office.

Horoszowski-Fridman, Y. B., Brêthes, J. C., Rahmani, N., and Rinkevich, B. (2015). Marine silviculture: Incorporating ecosystem engineering properties into reef restoration acts. Ecol. Eng. 82, 201-213. doi: 10.1016/j.ecoleng.2015.04.104

Hsing, P. Y., Fu, B., Larcom, E. A., Berlet, S. P., Shank, T. M., Govindarajan, A. F., et al. (2013). Evidence of lasting impact of the deepwater horizon oil spill on a deep Gulf of Mexico coral community. Elem. Sci. Anth. 1:12. doi: 10.12952/journal.elementa.000012

Hughes, R. G., and Paramor, O. A. L. (2004). On the loss of saltmarshes in southeast England and methods for their restoration. J. Appl. Ecol. 41, 440-448. doi: 10.1111/j.0021-8901.2004.00915.x

Huvenne, V. A. I., Bett, B. J., Masson, D. G., Le Bas, T. P., and Wheeler, A. J. (2016) Effectiveness of a deep-sea cold-water coral Marine Protected Area, following eight years of fisheries closure. Biol. Conserv. 200, 60-69. doi: 10.1016/j.biocon. 2016.05.030

Huvenne, V. A. I., Tyler, P. A., Masson, D. G., Fisher, E. H., Hauton, C., Hühnerbach, V., et al. (2011). A picture on the wall: Innovative mapping reveals cold-water coral refuge in submarine canyon. PLoS One 6:e028755. doi: 10.1371 /journal.pone.0028755

ICES and Hall-Spencer, J. (2007). Report of the working group on deep-water ecology, 26-28 February 2007.International Seabed Authority (2018). Draft regulations 
on the exploitation of mineral resources in the area. Available Online at: ISBA/24/LTC/WP.1. https://www.isa.org.jm/document/isba24ltcwp1rev1

IPBES. (2019). "Summary for policymakers of the global assessment report on biodiversity and ecosystem services," in The Intergovernmental Science-Policy Platform on Biodiversity and Ecosystem Services, eds S. Díaz, J. Settele, E. S. Brondízio, H. T. Ngo, M. Guèze, J. Agard, et al. (Bonn, Germany: IPBES secretariat), 56.

Jaap, W. C. (2000). Coral reef restoration. Ecol. Eng. 15, 345-364. doi: 10.1016/ S0925-8574(00)00085-9

Jackson, J. B. C. (2001). What was natural in the coastal oceans? Proc. Natl. Acad. Sci. U. S. A. 98, 5411-5418. doi: 10.1073/pnas.091092898

Jackson, L., Lopoukhine, N., and Hillyard, D. (1995). Ecological restoration: a definition and comments. Restor. Ecol. 3, 71-75. doi: 10.1111/j.1526-100X.1995. tb00079.x

Järnegren, J., Brooke, S., and Jensen, H. (2017). Effects of drill cuttings on larvae of the cold-water coral Lophelia pertusa. Deep. Res. Part II Top. Stud. Oceanogr. 137, 454-462. doi: 10.1016/j.dsr2.2016.06.014

Jones, C. G., Lawton, J. H., and Shachak, M. (1994). Organismms as ecosystems engineers. Nord. Soc. Oikos 69, 373-386.

Jones, H. P., Jones, P. C., Barbier, E. B., Blackburn, R. C., Rey Benayas, J. M., Holl, K. D., et al. (2018). Restoration and repair of Earth's damaged ecosystems. Proc. R. Soc. B Biol. Sci. 285:1873. doi: 10.1098/rspb.2017.2577

Jonsson, L., Dahl, M., Strömberg, S., Lindegarth, M., André, C., and Lundälv, T. (2015). In situ measurement of survival and growth of genotyped transplanted fragments of the cold-water coral Lophelia pertusa. Sweden: University of Gothenburg.

Joye, S. B., Bracco, A., Özgökmen, T. M., Chanton, J. P., Grosell, M., MacDonald, I. R., et al. (2016). The Gulf of Mexico ecosystem, six years after the Macondo oil well blowout. Deep. Res. Part II Top. Stud. Oceanogr. 129, 4-19. doi: 10.1016/ j.dsr2.2016.04.018

Kaiser, M. J., and Pulsipher, A. G. (2005). Rigs-to-reef programs in the Gulf of Mexico. Ocean Dev. Int. Law 36, 119-134. doi: 10.1080/0090832059094 3990

Kaiser, M. J., Shively, J. D., and Shipley, J. B. (2020). An Update on the Louisiana and Texas Rigs-to-Reefs programs in the Gulf of Mexico. Ocean Dev. Int. Law 51, 73-93. doi: 10.1080/00908320.2019.1636191

Kaly, U. L., and Jones, G. (1998). Mangrove restoration: a potential tool for coastal management in tropical developing countries. Ambio 27, 656-661. doi: 10.2307/ 4314812

Kihara, K., Taniguchi, H., Koibuchi, Y., Yamamoto, S., Kondo, Y., and Hosokawa, Y. (2013). Enhancing settlement and growth of corals using feeble electrochemical method. Galaxea J. Coral Reef Stud. 15, 323-329. doi: 10.3755/ galaxea.15.323

Kiriakoulakis, K., Fisher, E., Wolff, G. A., Freiwald, A., Grehan, A., and Roberts, J. M. (2005). "Lipids and nitrogen isotopes of two deep-water corals from the North-East Atlantic: initial results and implications for their nutrition," in ColdWater Corals and Ecosystems. Erlangen Earth Conference Series, eds A. Freiwald and J. M. Roberts (Berlin, Heidelberg: Springer), 715-729. doi: 10.1007/3-54027673-4_37

Koenig, C. C. (2001). Oculina Banks: Habitat, fish populations, restoration, and enforcement. Report to the South Atlantic fishery management council. Florida.

Kourti, N., Shepherd, I., Greidanus, H., Alvarez, M., Aresu, E., Bauna, T., et al. (2005). Integrating remote sensing in fisheries control. Fish. Manag. Ecol. 12, 295-307. doi: 10.1111/j.1365-2400.2005.00452.x

Kourti, N., Shepherd, I., Schwartz, G., and Pavlakis, P. (2001). Integrating spaceborne SAR imagery into operational systems for fisheries monitoring. Can. J. Remote Sens. 27, 291-305. doi: 10.1080/07038992.2001.1085 4872

Kurman, M. D., Gomez, C. E., Georgian, S. E., Lunden, J. J., and Cordes, E. E. (2017). Intra-specific variation reveals potential for adaptation to ocean acidification in a cold-water coral from the Gulf of Mexico. Front. Mar. Sci. 4:111. doi: 10.3389/fmars.2017.00111

Lacharité, M., and Metaxas, A. (2013). Early life history of deep-water gorgonian corals may limit their abundance. PLoS One 8:e65394. doi: 10.1371/journal. pone.0065394

Ladd, M. C., Miller, M. W., Hunt, J. H., Sharp, W. C., and Burkepile, D. E. (2018). Harnessing ecological processes to facilitate coral restoration. Front. Ecol. Environ. 16, 239-247. doi: 10.1002/fee.1792
Laegdsgaard, P. (2006). Ecology, disturbance and restoration of coastal saltmarsh in Australia: a review. Wetl. Ecol. Manag. 14, 379-399. doi: 10.1007/s11273005-8827-z

Larcom, E. A., McKean, D. L., Brooks, J. M., and Fisher, C. R. (2014). Growth rates, densities, and distribution of Lophelia pertusa on artificial structures in the Gulf of Mexico. Deep. Res. Part I Oceanogr. Res. Pap. 85, 101-109. doi: 10.1016/j.dsr.2013.12.005

Larsson, A. I., Järnegren, J., Strömberg, S. M., Dahl, M. P., Lundälv, T., and Brooke, S. (2014). Embryogenesis and larval biology of the cold-water coral Lophelia pertusa. PLoS One 9:e102222. doi: 10.1371/journal.pone.0102222

Larsson, A. I., van Oevelen, D., Purser, A., and Thomsen, L. (2013). Tolerance to long-term exposure of suspended benthic sediments and drill cuttings in the cold-water coral Lophelia pertusa. Mar. Pollut. Bull. 70, 176-188. doi: 10.1016/ j.marpolbul.2013.02.033

Lartaud, F., Pareige, S., de Rafelis, M., Feuillassier, L., Bideau, M., Peru, E., et al. (2013). A new approach for assessing cold-water coral growth in situ using fluorescent calcein staining. Aquat. Living Resour. 26, 187-196.

Lartaud, F., Pareige, S., de Rafelis, M., Feuillassier, L., Bideau, M., Peru, E., et al. (2014). Temporal changes in the growth of two Mediterranean cold-water coral species, in situ and in aquaria. Deep. Res. Part II Top. Stud. Oceanogr. 99, 64-70. doi: 10.1016/j.dsr2.2013.06.024

Layton, C., Coleman, M. A., Marzinelli, E. M., Steinberg, P. D., Swearer, S. E., Vergés, A., et al. (2020). Kelp forest restoration in Australia. Front. Mar. Sci. 7:74. doi: 10.3389/fmars.2020.00074

Levin, L. A., Mengerink, K., Gjerde, K. M., Rowden, A. A., Van Dover, C. L., Clark, M. R., et al. (2016). Defining "serious harm" to the marine environment in the context of deep-seabed mining. Mar. Policy 74, 245-259. doi: 10.1016/j.marpol. 2016.09.032

Levitan, D. R. (1991). Influence of body size and population density on fertilization success and reproductive output in a free-spawning invertebrate. Biol. Bull. 181, 261-268. doi: 10.2307/1542097

Linares, C., Coma, R., and Zabala, M. (2008). Restoration of threatened red gorgonian populations: An experimental and modelling approach. Biol. Conserv. 141, 427-437. doi: 10.1016/j.biocon.2007.10.012

Lindahl, U. (2003). Coral reef rehabilitation through transplantation of staghorn corals: effects of artificial stabilization and mechanical damages. Coral Reefs 22, 217-223. doi: 10.1007/s00338-003-0305-6

Lotze, H. K., Coll, M., Magera, A. M., Ward-Paige, C., and Airoldi, L. (2011). Recovery of marine animal populations and ecosystems. Trends Ecol. Evol. 26, 595-605. doi: 10.1016/j.tree.2011.07.008

Macreadie, P. I., Fowler, A. M., and Booth, D. J. (2011). Rigs-to-reefs: will the deep sea benefit from artificial habitat? Front. Ecol. Environ. 9, 455-461. doi: $10.1890 / 100112$

Manea, E., Bianchelli, S., Fanelli, E., Danovaro, R., and Gissi, E. (2020). Towards an ecosystem-based marine spatial planning in the deep Mediterranean Sea. Sci. Total Environ. 715:136884. doi: 10.1016/j.scitotenv.2020.13 6884

Marrs, S., and Hall-Spencer, J. M. (2002). UK coral reefs. Ecologist 32, 36-37.

Martín, J., Puig, P., Palanques, A., and Ribó, M. (2014). Trawling-induced daily sediment resuspension in the flank of a Mediterranean submarine canyon. Deep. Res. Part II Top. Stud. Oceanogr. 104, 174-183. doi: 10.1016/j.dsr2.2013. 05.036

MBARI. (2016). MBARI (Monterey Bay Aquarium Resarch Institute) Annual report. Moss Landing: MBARI, 78.

McAfee, D., Doubleday, Z. A., Geiger, N., and Connell, S. D. (2019). Everyone loves a success story: Optimism inspires conservation engagement. Bioscience 69, 274-281. doi: 10.1093/biosci/biz019

McDonald, T., Gann, G., Jonson, J., and Dixon, K. (2016). International standards for the practice of ecological restoration - including principles and key concepts. Washington, D.C: Society for Ecological Restoration.

Medrano, A., Hereu, B., Cleminson, M., Pagès-Escolà, M., Rovira, G., Solà, J., et al. (2020). From marine deserts to algal beds: Treptacantha elegans revegetation to reverse stable degraded ecosystems inside and outside a No-Take marine reserve. Restor. Ecol. 28, 632-644. doi: 10.1111/rec.13123

Mercier, A., and Hamel, J. F. (2011). Contrasting reproductive strategies in three deep-sea octocorals from eastern Canada: Primnoa resedaeformis, Keratoisis ornata, and Anthomastus grandiflorus. Coral Reefs 30, 337-350. doi: 10.1007/ s00338-011-0724-8 
Middelburg, J. J., Mueller, C. E., Veuger, B., Larsson, A. I., Form, A., and Van Oevelen, D. (2015). Discovery of symbiotic nitrogen fixation and chemoautotrophy in cold-water corals. Sci. Rep. 5, 1-9. doi: 10.1038/srep17962

Millennium Ecosystem Assessment. (2005). Ecosystems and human well-being: Synthesis. Washington, D.C: Island Press.

Miller, K. A., Thompson, K. F., Johnston, P., and Santillo, D. (2018). An overview of seabed mining including the current state of development, environmental impacts, and knowledge gaps. Front. Mar. Sci. 4:418. doi: 10.3389/fmars.2017. 00418

Mitsch, W. J. (2014). When will ecologists learn engineering and engineers learn ecology? Ecol. Eng. 65, 9-14. doi: 10.1016/j.ecoleng.2013.10.002

Montero-Serra, I., Garrabou, J., Doak, D. F., Figuerola, L., Hereu, B., Ledoux, J. B., et al. (2018). Accounting for life-history strategies and timescales in marine restoration. Conserv. Lett. 11, 1-9. doi: 10.1111/conl.12341

Montoya-Maya, P. H., Smit, K. P., Burt, A. J., and Frias-Torres, S. (2016). Largescale coral reef restoration could assist natural recovery in Seychelles, Indian Ocean. Nat. Conserv. 16, 1-17. doi: 10.3897/natureconservation.16.8604

Montseny, M., Linares, C., Viladrich, N., Capdevila, P., Ambroso, S., Díaz, D., et al. (2020). A new large-scale and cost-effective restoration method for coldwater coral gardens. Aquat. Conserv. Mar. Freshw. Ecosyst. 30, 977-987. doi: 10.1002 /aqc. 3303

Montseny, M., Linares, C., Viladrich, N., Olariaga, A., Carreras, M., Palomeras, N., et al. (2019). First attempts towards the restoration of gorgonian populations on the Mediterranean continental shelf. Aquat. Conserv. Mar. Freshw. Ecosyst. 29, 1278-1284. doi: 10.1002/aqc.3118

Morato, T., González-Irusta, J., Dominguez-Carrió, C., Wei, C., Davies, A., Sweetman, A. K., et al. (2020). Climate-induced changes in the suitable habitat of cold-water corals and commercially important deep-sea fishes in the North Atlantic. Glob. Chang. Biol. 26, 2181-2202. doi: 10.1111/gcb. 14996

Morikawa, M. K., and Palumbi, S. R. (2019). Using naturally occurring climate resilient corals to construct bleaching-resistant nurseries. PNAS 116, 1058610591. doi: 10.1073/pnas.1721415116

Morris, K. J., Bett, B. J., Durden, J. M., Huvenne, V. A. I., Milligan, R., Jones, D. O. B., et al. (2014). A new method for ecological surveying of the abyss using autonomous underwater vehicle photography. Limnol. Oceanogr. Methods 12, 795-809. doi: 10.4319/lom.2014.12.795

Movilla, J., Orejas, C., Calvo, E., Gori, A., López-Sanz, À, Grinyó, J., et al. (2014). Differential response of two Mediterranean cold-water coral species to ocean acidification. Coral Reefs 33, 675-686. doi: 10.1007/s00338-014-1159-9

Mueller, C. E., Larsson, A. I., Veuger, B., Middelburg, J. J., and Van Oevelen, D. (2013a). Opportunistic feeding on various organic food sources by the coldwater coral Lophelia pertusa. Biogeosciences 11, 123-133. doi: 10.5194/bg-11123-2014

Mueller, C. E., Lundälv, T., Middelburg, J. J., and van Oevelen, D. (2013b). The symbiosis between Lophelia pertusa and Eunice norvegica stimulates coral calcification and worm assimilation. PLoS One 8:e058660. doi: 10.1371/journal. pone. 0058660

Mura, D., Barbarossa, M., Dinuzzi, G., Grioli, G., Caiti, A., and Catalano, M. G. (2018). A Soft modular end effector for underwater manipulation: a gentle, adaptable grasp for the ocean depths. IEEE Robot. Autom. Mag. 25, 45-56. doi: 10.1109/MRA.2018.2871350

Ng, C. S. L., Lim, S. C., Ong, J. Y., Teo, L. M. S., Chou, L. M., Chua, K. E., et al. (2015). Enhancing the biodiversity of coastal defence structures: Transplantation of nursery-reared reef biota onto intertidal seawalls. Ecol. Eng. 82, 480-486. doi: 10.1016/j.ecoleng.2015.05.016

Orejas, C., Ferrier-Pagès, C., Reynaud, S., Gori, A., Beraud, E., Tsounis, G., et al. (2011). Long-term growth rates of four Mediterranean cold-water coral species maintained in aquaria. Mar. Ecol. Prog. Ser. 429, 57-65. doi: 10.3354/ meps09104

Orejas, C., Gili, J. M., López-González, P. J., Hasemann, C., and Arntz, W. E. (2007). Reproduction patterns of four Antarctic octocorals in the Weddell Sea: an inter-specific, shape, and latitudinal comparison. Mar. Biol. 150, 551-563. doi: 10.1007/s00227-006-0370-9

Orejas, C., Gori, A., and Gili, J. M. (2008). Growth rates of live Lophelia pertusa and Madrepora oculata from the Mediterranean Sea maintained in aquaria. Coral Reefs 27:255. doi: 10.1007/s00338-007-0350-7
Orejas, C., Taviani, M., and Ambroso, S. (2019). “Cold-water coral in aquaria: advances and challenges. A focus on the Mediterranean," in Mediterranean coldwater corals: past, present and future. Coral Reefs of the World, Vol. 9, eds C. Orejas and C. Jiménez (Cham: Springer).

OSPAR. (2009). Background Document for Lophelia pertusa reefs. Biodiversity Series. Publication Number: 423/2009. London, UK: OSPAR Commission.

OSPAR. (2010). Background document for coral gardens. Biodiversity Series. Publication Number: 486/2010. London, UK: OSPAR Commission.

Ounanian, K., Carballo-Cárdenas, E., van Tatenhove, J. P. M., Delaney, A., Papadopoulou, K. N., and Smith, C. J. (2018). Governing marine ecosystem restoration: the role of discourses and uncertainties. Mar. Policy 96, 136-144. doi: 10.1016/j.marpol.2018.08.014

Paling, E. I., Fonseca, M., van Katwijk, M. M., and van Keulen, M. (2009). "Seagrass restoration," in Coastal wetlands: An Integrated Ecosystems Approach, eds G. M. E. Perillo, E. Wolanski, D. R. Cahoon, and M. M. Brinson (Amsterdam: Elsevier), 687-713.

Pedersen, N. E., Edwards, C. B., Eynaud, Y., Gleason, A. C. R., Smith, J. E., and Sandin, S. A. (2019). The influence of habitat and adults on the spatial distribution of juvenile corals. Ecography (Cop.). 42, 1703-1713. doi: 10.1111/ ecog. 04520

Pham, C. K., Diogo, H., Menezes, G., Porteiro, F., Braga-Henriques, A., Vandeperre, F., et al. (2014). Deep-water longline fishing has reduced impact on Vulnerable Marine Ecosystems. Sci. Rep. 4, 1-6. doi: 10.1038/srep04837

Pizarro, V., Carrillo, V., and García-Rueda, A. (2014). Review and state of the art for ecological restoration of coral reefs. Biota Colomb. 15, 132-149.

Pollock, F. J., Katz, S. M., van de Water, J. A. J. M., Davies, S. W., Hein, M., Torda, G., et al. (2017). Coral larvae for restoration and research: a large-scale method for rearing Acropora millepora larvae, inducing settlement, and establishing symbiosis. PeerJ 5:e3732. doi: 10.7717/peerj.3732

Possingham, H. P., Bode, M., and Klein, C. J. (2015). Optimal conservation outcomes require both restoration and protection. PLoS Biol. 13:e1002052. doi: 10.1371/journal.pbio.1002052

Prado, E., Sánchez, F., Rodríguez-Basalo, A., Altuna, Á, and Cobo, A. (2019). Analysis of the population structure of a gorgonian forest (Placogorgia sp.) using a photogrammetric 3D modeling approach at Le Danois Bank, Cantabrian Sea. Deep. Res. Part I Oceanogr. Res. Pap. 153:103124. doi: 10.1016/j.dsr.2019. 103124

Precht, W. F., and Robbart, M. (2006). "Coral reef restoration: the rehabilitation of an ecosystem under siege," in Coral Reef Restoration Handbook, ed. W. F. Precht (Boca Raton, FL: CRC Press), 24.

Primavera, J. H., and Esteban, J. M. A. (2008). A review of mangrove rehabilitation in the Philippines: successes, failures and future prospects. Wetl. Ecol. Manag. 16, 345-358. doi: 10.1007/s11273-008-9101-y

Proffitt, C. E., and Devlin, D. J. (2005). Long-term growth and succession in restored and natural mangrove forests in southwestern Florida. Wetl. Ecol. Manag. 13, 531-551. doi: 10.1007/s11273-004-2411-9

Puerta, P., Johnson, C., Carreiro-Silva, M., Henry, L. A., Kenchington, E., Morato, T., et al. (2020). Influence of water masses on the biodiversity and biogeography of deep-sea benthic ecosystems in the North Atlantic. Front. Mar. Sci. 7:239. doi: $10.3389 /$ fmars.2020.00239

Puig, P., Canals, M., Company, J. B., Martín, J., Amblas, D., Lastras, G., et al. (2012). Ploughing the deep sea floor. Nature 489, 286-289. doi: 10.1038/nature11410

Purkey, S. G., and Johnson, G. C. (2010). Warming of global abyssal and deep Southern Ocean waters between the 1990s and 2000s: Contributions to global heat and sea level rise budgets. J. Clim. 23, 6336-6351. doi: 10.1175/ 2010JCLI3682.1

Pusceddu, A., Bianchelli, S., Martín, J., Puig, P., Palanques, A., Masqué, P., et al. (2014). Chronic and intensive bottom trawling impairs deep-sea biodiversity and ecosystem functioning. Proc. Natl. Acad. Sci. U. S. A. 111, 8861-8866. doi: 10.1073/pnas.1405454111

Pyle, R. L., and Copus, J. M. (2019). "Mesophotic coral ecosystems: introduction and overview," in Mesophotic Coral Ecosystems. Coral Reefs of the World, Vol. 12, eds Y. Loya, K. Puglise, and T. Bridge (Cham: Springer), 3-27.

Ragnarsson, S. Á, Burgos, J. M., Kutti, T., Beld, I., Van Den, Egilsdóttir, H., Arnaudhaond, S., et al. (2017). "The impact of anthropogenic activity on cold-water corals," in Marine Animal Forests, eds S. Rossi, L. Bramanti, A. Gori, and C. Orejas (Cham: Springer International Publishing). 
Ramirez-Llodra, E., Tyler, P. A., Baker, M. C., Bergstad, O. A., Clark, M. R., Escobar, E., et al. (2011). PLoS One 6:e22588. doi: 10.1371/journal.pone.0022588

Reed, J. K. (1981). In situ growth rates of the scleractinian coral Oculina variciosa occuring with zooxanthellae on $6 \mathrm{~m}$ reefs and without on $80 \mathrm{~m}$ banks. Proc. Fourth Int. Coral Reef Symp. 2, 201-206.

Reynaud, S., and Ferrier-Pagès, C. (2019). "Biology and ecophysiology of Mediterranean cold-water corals," in Mediterranean Cold-water corals: past, present and future. Coral Reefs of the World, Vol. 9, eds C. Orejas and C. Jiménez (Cham: Springer).

Rijnsdorp, A. D., Bastardie, F., Bolam, S. G., Buhl-Mortensen, L., Eigaard, O. R., Hamon, K. G., et al. (2016). Towards a framework for the quantitative assessment of trawling impact on the seabed and benthic ecosystem. ICES J. Mar. Sci. 73, i127-i138. doi: 10.1093/icesjms/fsv207

Rinkevich, B. (1995). Restoration strategies for coral reefs damaged by recreational activities: The use of sexual and asexual recruits. Restor. Ecol. 3, 241-251.

Rinkevich, B. (2005). Conservation of coral reefs through active restoration measures: recent approaches and last decade progress. Environ. Sci. Technol. 39, 4333-4342. doi: 10.1021/es0482583

Rinkevich, B. (2014). Rebuilding coral reefs: does active reef restoration lead to sustainable reefs? Curr. Opin. Environ. Sustain. 7, 28-36. doi: 10.1016/j.cosust. 2013.11.018

Risk, M. J., Heikoop, J. M., Snow, M. G., and Beukens, R. (2002). Lifespans and growth patterns of two deep-sea corals: Primnoa resedaeformis and Desmophyllum cristagalli. Hydrobiologia 471, 125-131. doi: 10.1023/A: 1016557405185

Rix, L., De Goeij, J. M., Mueller, C. E., Struck, U., Middelburg, J. J., Van Duyl, F. C., et al. (2016). Coral mucus fuels the sponge loop in warm-and cold-water coral reef ecosystems. Sci. Rep. 6, 1-11. doi: 10.1038/srep18715

Roark, E. B., Guilderson, T. P., Dunbar, R. B., Fallon, S. J., and Mucciarone, D. A. (2009). Extreme longevity in proteinaceous deep-sea corals. Proc. Natl. Acad. Sci. U. S. A. 106, 5204-5208. doi: 10.1073/pnas.0810875 106

Roberts, C. (2002). Deep impact: the rising toll of fishing in the deep sea. Trends Ecol. Evol. 17, 242-245. doi: 10.1016/S0169-5347(02)02492-8

Roberts, J. M., Wheeler, A. J., Freiwald, A., and Cairns, S. D. (2009). Cold-watercorals: the biology and geology of deep-sea coral habitats. Cambrige: Cambrige University Press.

Roberts, J. M., Wheeler, A., and Freiwald, A. (2006). Reefs of the deep: the biology and geology of cold-water coral ecosystems. Science 80, 543-548. doi: 10.1126/ science.1119861

Rogers, A. D. (1999). The biology of Lophelia pertusa (L innaeus 1758) and other deep-water reef-forming corals and impacts from human activities. Int. Rev. Hydrobiol. 84, 315-406. doi: 10.1002/iroh.19990 0032

Rovelli, L., Attard, K. M., Bryant, L. D., Flögel, S., Stahl, H., Roberts, J. M., et al. (2015). Benthic $\mathrm{O}_{2}$ uptake of two cold-water coral communities estimated with the non-invasive eddy correlation technique. Mar. Ecol. Prog. Ser. 525, 97-104. doi: 10.3354/meps11211

Ruiz-Jaen, M. C., and Mitchell Aide, T. (2005). Restoration Success: how is it being measured? Restor. Ecol. 13, 569-577. doi: 10.1111/j.1526-100X.2005.00072.x

Sahoo, A., Dwivedy, S. K., and Robi, P. S. (2019). Advancements in the field of autonomous underwater vehicle. Ocean Eng. 181, 145-160. doi: 10.1016/j. oceaneng.2019.04.011

Sammarco, P. W., Porter, S. A., and Cairns, S. D. (2010). A new coral species introduced into the Atlantic ocean - Tubastraea micranthus (Ehrenberg 1834) (Cnidaria, Anthozoa, Scleractinia): an invasive threat? Aquat. Invasions 5, 131-140. doi: 10.3391/ai.2010.5.2.02

Sampaio, I., Braga-Henriques, A., Pham, C., Ocaña, O., De Matos, V., Morato, T., et al. (2012). Cold-water corals landed by bottom longline fisheries in the Azores (north-eastern Atlantic). J. Mar. Biol. Assoc. U K. 92, 1547-1555. doi: $10.1017 /$ S0025315412000045

Sayer, M. D. J., Fischer, P., and Féral, J. (2008). "Diving for science 2008," in Proceedings of the American Academy of Underwater Sciences 27th Symposium, eds P. Brueggeman and N. W. Pollock (Dauphin Island, Ala: American Academy of Underwater Sciences), 139-146.

Shabtay, A., Portman, M. E., Manea, E., and Gissi, E. (2019). Promoting ancillary conservation through marine spatial planning. Sci. Total Environ. 651, 17531763. doi: 10.1016/j.scitotenv.2018.10.074
Sherwood, O. A., and Edinger, E. N. (2009). Ages and growth rates of some deepsea gorgonian and antipatharian corals of Newfoundland and Labrador. Can. J. Fish. Aquat. Sci. 66, 142-152. doi: 10.1139/F08- 195

Spurgeon, J. P. G., and Lindahl, U. (2000). "Economics of coral reef restoration," in Collected Essays on the Economics of Coral Reefs, ed. CORDIO (Kalmar: Department for Biology and Environmental Sciences, Kalmar University), 125-136.

Stachowicz, J. J. (2001). Mutualism, facilitation, and the structure of ecological communities: positive interactions play a critical, but underappreciated, role in ecological communities by reducing physical or biotic stresses in existing habitats and by creating new habitats on w. Bioscience 51, 235-246.

Strömberg, S. M. (2016). Early history of the cold-water coral Lophelia pertusa- with implications for dispersal. Dr. thesis. Sweden: University of Gothenburg.

Strömberg, S. M., and Larsson, A. I. (2017). Larval behavior and longevity in the cold-water coral lophelia pertusa indicate potential for long distance dispersal. Front. Mar. Sci. 4:411. doi: 10.3389/fmars.2017.00411

Strömberg, S. M., Lundälv, T., and Goreau, T. J. (2010). Suitability of mineral accretion as a rehabilitation method for cold-water coral reefs. J. Exp. Mar. Bio. Ecol. 395, 153-161. doi: 10.1016/j.jembe.2010.08.028

Strömberg, S. M., Östman, C., and Larsson, A. I. (2019). The cnidome and ultrastructural morphology of late planulae in Lophelia pertusa (Linnaeus, 1758)-With implications for settling competency. Acta Zool. 100, 431-450. doi: 10.1111/azo.12296

Sture, O., Ludvigsen, M., Scheide, M. S., and Thorsnes, T. (2018). Recognition of cold-water corals in synthetic aperture sonar Imagery. in 2018 IEEE/OES Autonomous Underwater Vehicle Workshop (AUV). New York: IEEE, 1-6.

Sweetman, A. K., Thurber, A. R., Smith, C. R., Levin, L. A., Mora, C., Wei, C. L., et al. (2017). Major impacts of climate change on deep-sea benthic ecosystems. Elem. Sci. Anth. 5:4. doi: 10.1525/elementa.203

Tamburello, L., Papa, L., Guarnieri, G., Basconi, L., Zampardi, S., Scipione, M. B., et al. (2019). Are we ready for scaling up restoration actions? An insight from Mediterranean macroalgal canopies. PLoS One 14:e0224477. doi: 10.1371/ journal.pone.0224477

Thornton, B., Bodenmann, A., Pizarro, O., Williams, S. B., Friedman, A., Nakajima, R., et al. (2016). Biometric assessment of deep-sea vent megabenthic communities using multi-resolution 3D image reconstructions. Deep. Res. Part I Oceanogr. Res. Pap. 116, 200-219. doi: 10.1016/j.dsr.2016.08.009

Thresher, R. E., Guinotte, J. M., Matear, R. J., and Hobday, A. J. (2015). Options for managing impacts of climate change on a deep-sea community. Nat. Clim. Chang. 5, 635-639. doi: 10.1038/nclimate2611

Thresher, R. E., Tilbrook, B., Fallon, S., Wilson, N. C., and Adkins, J. (2011). Effects of chronic low carbonate saturation levels on the distribution, growth and skeletal chemistry of deep-sea corals and other seamount megabenthos. Mar. Ecol. Prog. Ser. 442, 87-96. doi: 10.3354/meps09400

Thurber, A. R., Sweetman, A. K., Narayanaswamy, B. E., Jones, D. O. B., Ingels, J., and Hansman, R. L. (2014). Ecosystem function and services provided by the deep sea. Biogeosciences 11, 3941-3963. doi: 10.5194/bg-11-3941-2014

Treml, E. A., Ford, J. R., Black, K. P., and Swearer, S. E. (2015). Identifying the key biophysical drivers, connectivity outcomes, and metapopulation consequences of larval dispersal in the sea. Mov. Ecol. 3, 1-16. doi: 10.1186/s40462-015 $-0045-6$

Van Dover, C. L., Aronson, J., Pendleton, L., Smith, S., Arnaud-Haond, S., Moreno-Mateos, D., et al. (2014). Ecological restoration in the deep sea: Desiderata. Mar. Policy 44, 98-106. doi: 10.1016/j.marpol.2013 .07 .006

Van Engeland, T., Godø, O. R., Johnsen, E., Duineveld, G. C. A., and van Oevelen, D. (2019). Cabled ocean observatory data reveal food supply mechanisms to a cold-water coral reef. Prog. Oceanogr. 172, 51-64. doi: 10.1016/j.pocean.2019. 01.007

van Katwijk, M. M., Bos, A. R., de Jonge, V. N., Hanssen, L. S. A. M., Hermus, D. C. R., and de Jong, D. J. (2009). Guidelines for seagrass restoration: Importance of habitat selection and donor population, spreading of risks, and ecosystem engineering effects. Mar. Pollut. Bull. 58, 179-188. doi: 10.1016/j. marpolbul.2008.09.028

van Katwijk, M. M., Thorhaug, A., Marbà, N., Orth, R. J., Duarte, C. M., Kendrick, G. A., et al. (2016). Global analysis of seagrass restoration: the importance of large-scale planting. J. Appl. Ecol. 53, 567-578. doi: 10.1111/1365-2664.12562 
van Oppen, M. J., Oliver, J. K., Putnam, H. M., and Gates, R. D. (2015). Building coral reef resilience through assisted evolution. PNAS 112, 2307-2313. doi: $10.1073 /$ pnas. 1422301112

Verdura, J., Sales, M., Ballesteros, E., Cefalì, M. E., and Cebrian, E. (2018). Restoration of a canopy-forming alga based on recruitment enhancement: methods and long-term success assessment. Front. Plant Sci. 9:1832. doi: 10. 3389/fpls.2018.01832

Waller, R. G. (2005). "Deep-water Scleractinia (Cnidaria: Anthozoa): current knowledge of reproductive processes," in Cold-Water Corals and Ecosystems, eds A. Freiwald and J. M. Roberts (Berlin: Springer-Verlag), 691-700.

Wareham, V. E., and Edinger, E. N. (2007). Distribution of deep-sea corals in the Newfoundland and Labrador region, Northwest Atlantic Ocean. Bull. Mar. Sci. 81, 289-313.

Watanabe, S., Metaxas, A., Sameoto, J., and Lawton, P. (2009). Patterns in abundance and size of two deep-water gorgonian octocorals, in relation to depth and substrate features off Nova Scotia. Deep. Res. Part I Oceanogr. Res. Pap. 56, 2235-2248. doi: 10.1016/j.dsr.2009.09.003

Watling, L., France, S. C., Pante, E., and Simpson, A. (2011). Biology of deepwater octocorals. Adv. Mar. Biol. 60, 41-122. doi: 10.1016/B978-0-12-3855299.00002-0

Wattage, P., Glenn, H., Mardle, S., Van Rensburg, T., Grehan, A., and Foley, N. (2011). Economic value of conserving deep-sea corals in Irish waters: a choice experiment study on marine protected areas. Fish. Res. 107, 59-67. doi: 10.1016/j.fishres.2010.10.007

Weinberg, S. (1979). Transplantation experiments with mediterranean gorgonians. Bijdr. tot Dierkd. 49, 31-41.

Weinnig, A. M., Gómez, C. E., Hallaj, A., and Cordes, E. E. (2020). Cold-water coral (Lophelia pertusa) response to multiple stressors: High temperature affects recovery from short-term pollution exposure. Sci. Rep. 10:1768. doi: 10.1038/ s41598-020-58556-9

Wheeler, A., Bett, B., Billett, D., Masson, D., and Mayor, D. (2004). "The impact of demersal trawling on NE Atlantic deep-water coral habitats: the case of the Darwin Mounds, U.K,' in Benthic Habitats and the Effects of Fishing, Vol. 41, eds P. Barnes and J. Thomas (Bethesda, Maryland, USA: American Fisheries Society), 807-817.

White, H. K., Hsing, P.-Y., Cho, W., Shank, T. M., Cordes, E. E., Quattrini, A. M., et al. (2012). Impact of the Deepwater Horizon oil spill on a deep-water coral community in the Gulf of Mexico. Proc. Natl. Acad. Sci. 109, 20303-20308. doi: 10.1073/pnas.1118029109
Wild, C., Naumann, M. S., Haas, A., Struck, U., Mayer, F. W., Rasheed, M. Y., et al. (2009). Coral sand $\mathrm{O}_{2}$ uptake and pelagic-benthic coupling in a subtropical fringing reef, Aqaba, Red Sea. Aquat. Biol. 6, 133-142. doi: 10.3354/ab00181

Wildish, D., and Kristmanson, D. (1997). Benthic supensipn feeders and flow. Cambrige, UK: Cambrige University Press.

Williams, A., Schlacher, T. A., Rowden, A. A., Althaus, F., Clark, M. R., Bowden, D. A., et al. (2010). Seamount megabenthic assemblages fail to recover from trawling impacts. Mar. Ecol. 31, 183-199. doi: 10.1111/j.1439-0485.2010.0 0385.x

Yap, H. T. (2000). The case for restoration of tropical coastal ecosystems. Ocean Coast. Manag. 43, 841-851. doi: 10.1016/S0964-5691(00)00061-2

Young, C. N., Schopmeyer, S. A., and Lirman, D. (2012). A review of reef restoration and coral propagation using the threatened genus Acropora in the Caribbean and western Atlantic. Bull. Mar. Sci. 88, 1075-1098. doi: 10.5343/bms.2011.1143

Author Disclaimer: This output reflects only the authors' view and the European Union cannot be held responsible for any use that may be made of the information contained therein.

Conflict of Interest: The authors declare that the research was conducted in the absence of any commercial or financial relationships that could be construed as a potential conflict of interest.

Publisher's Note: All claims expressed in this article are solely those of the authors and do not necessarily represent those of their affiliated organizations, or those of the publisher, the editors and the reviewers. Any product that may be evaluated in this article, or claim that may be made by its manufacturer, is not guaranteed or endorsed by the publisher.

Copyright (c) 2021 Montseny, Linares, Carreiro-Silva, Henry, Billett, Cordes, Smith, Papadopoulou, Bilan, Girard, Burdett, Larsson, Strömberg, Viladrich, Barry, Baena, Godinho, Grinyó, Santín, Morato, Sweetman, Gili and Gori. This is an open-access article distributed under the terms of the Creative Commons Attribution License (CC BY). The use, distribution or reproduction in other forums is permitted, provided the original author(s) and the copyright owner(s) are credited and that the original publication in this journal is cited, in accordance with accepted academic practice. No use, distribution or reproduction is permitted which does not comply with these terms. 